\title{
Paleocene and Eocene deposits on the eastern margin of the Gulf of Gdańsk (Yantarny P-1 borehole, Kaliningrad region, Russia)
}

\author{
Jacek Robert KASIŃSKI ${ }^{1}$, Regina KRAMARSKA ${ }^{2}$, Barbara SŁODKOWSKA ${ }^{1, *}$, Vadim SIVKOV ${ }^{3,4}$ \\ and Marcin PIWOCKI ${ }^{1}$ \\ 1 Polish Geological Institute - National Research Institute, Rakowiecka 4, 00-975 Warszawa, Poland \\ 2 Polish Geological Institute - National Research Institute, Marine Geology Branch, Kościerska 5, 80-328 Gdańsk, Poland \\ 3 Russian Academy of Sciences, Shirshov Institute of Oceanology, Atlantic Branch, Prospekt Mira 1, 236022 Kaliningrad, \\ Russia \\ 4 Immanuel Kant Baltic Federal University, A. Nevskogo 14, 236041 Kaliningrad, Russia
}

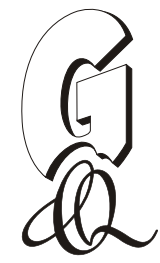

\begin{abstract}
Kasiński, J.R., Kramarska, R., Słodkowska, B., Sivkov, V., Piwocki, M., 2020. Paleocene and Eocene deposits on the eastern margin of the Gulf of Gdańsk (Yantarny P-1 borehole, Kaliningrad region, Russia). Geological Quarterly, 64 (1): 29-53,
\end{abstract} doi: $10.7306 / g q .1513$

Associate Editor: Michał Zatoń

\begin{abstract}
Lithological and palynological studies of Paleogene siliciclastic deposits from the Yantarny P-1 borehole located on the western coast of the Sambian Peninsula (Kaliningrad region, Russia) show that the succession is characterized by numerous sedimentary discontinuities related to lithification horizons and erosional surfaces. Sedimentary gaps are emphasised by hardgrounds. Palynological data suggest the Selandian-Priabonian age of the succession and indicate a number of significant stratigraphic gaps. An important change in heavy mineral composition is recognized between the Paleocene and Eocene deposits in the area studied. A significant number of reworked Cretaceous microfossils is observed in the Selandian part of the succession studied.
\end{abstract}

Key words: Paleogene, depositional structures, heavy minerals, palynology, Sambian Peninsula, Russia.

\section{INTRODUCTION}

Paleogene deposits of the Sambian Peninsula (Kaliningrad region) have been recognized in several boreholes and opencast amber mines (Zagorodnykh and Kunayeva, 2005). Upper Cretaceous (mostly Campanian) deposits constitute the sub-Cenozoic platform cover in the area. The top surface of the sub-Cenozoic succession is located beneath $60 \mathrm{~m}$ b.s.l. The area is extensively covered by Paleogene, Neogene and Quaternary sediments (Zagorodnykh and Kunayeva, 2005).

Zaddach (1867) presented the first outline of the geological setting of Sambia and named the amber-bearing deposits as "Blue Earth" ("Blaue Erde"). The distribution of Eocene deposits was described by Jentzsch (1876) and supplemented by Kaunhowen (1914). Later, studies of Paleogene deposits focused mostly on the palaeogeography and lithostratigraphy (Noetling, 1888; Eisenack, 1954; Katinas, 1971; Blazhchishin,

\footnotetext{
* Corresponding author, e-mail: barbara.slodkowska@pgi.gov.pl
} Received: August 7, 2018; accepted: December 3, 2019; first published online: March 2, 2020
1974; Krasnov and Kaplan, 1976; Kaplan et al., 1977; Grigelis et al., 1971, 1988; Kosmowska-Ceranowicz et al., 1997; Standke, 1998). The first dinocyst studies in Sambia were made by Alfred Eisenack $(1938,1954)$. Later, a few palynological studies were made in 1970-1980s (Zatula, 1973; Grigelis et al., 1988). A detailed palynological investigation of the succession studied has previously been made by Alexandrova and Zaporozhets (2008a, b).

Heavy minerals analysis plays significant role in palaeogeographic analysis here, particularly in searching for source areas of the amber-bearing deposits (Katinas, 1971; Kosmowska-Ceranowicz et al., 1997). A synthetic lithostratigraphic scheme for the Paleogene of the Sambian Peninsula was provided by Zagorodnykh et al. (2001).

An updated study of Paleogene deposits is important for the reconstruction of the Paleogene palaeogeography and palaeoenviroments of the Sambian Peninsula; Paleocene-Lower Eocene deposits are not exposed along the coast here and may be investigated only in borehole cores.

In this study we provide a combined biostratigraphic and mineralogical analysis of Paleocene-Eocene deposits from the borehole P-1 located on the eastern margin of the Gulf of Gdańsk. 


\section{GEOLOGICAL SETTING OF THE EASTERN MARGIN OF THE GULF OF GDAŃSK}

Campanian-Maastrichtian strata in the southern part of the study area (from the Vistula Spit), represented by marls and siltstones, compose the sub-Paleogene bedrock of the eastern margin of the Gulf of Gdańsk. Paleocene and Eocene deposits are known from the eastern part of the study area, being eroded closer to the centre of the Gulf of Gdańsk. They were deposited in the far offshore zone of the shallow siliciclastic shelf of an epicontinental sea (e.g., Katinas, 1971; Kasiński and Kramarska, 2008; Kramarska et al., 2008). From the Lutetian there began an interval of coastline oscillations as a result of minor marine transgressions and regressions, recorded by sedimentary cyclicity within the Middle and Upper Eocene strata. Amber occurrence is related to the deposition of fine to medium-grained clastic sediments. Amber distribution seems to have been affected by alongshore currents, that caused redeposition of the amber-bearing sediments (Krasnov and Kaplan, 1976; Kasiński and Tołkanowicz, 1999; Knox et al., 2010; Kasiński and Słodkowska, 2014). In turn, other interpretations have connected the origin of the amber-bearing deposits with the development of large deltas (Katinas, 1971; Jaworowski, 1987).

The Paleogene succession in the eastern part of the Gulf of Gdańsk is represented by four lithostratigraphic units (from base to top).

The Lubava Formation (Kaplan et al., 1977) comprises calcareous siltstones and partly decalcified with glauconite and muscovite, which are locally silicified. It is over $13 \mathrm{~m}$ thick, represented by grey-greenish glauconitic-quartz mudstones with muscovite and foraminifers, cemented with clay/carbonate. Based on foraminiferal data, this formation was attributed to the mid Paleocene (Selandian). The lithology of the Lubava Formation is diverse and so an equivalent Romanovo Formation is distinguished, with the hypostratotype defined in borehole No. 3 in Romanovo near Pionersk (Zagorodnykh et al., 2001). The Lubava Formation is $>13 \mathrm{~m}$ thick, represented by grey-greenish glauconite-quartz mudstones with muscovite and foraminifers, cemented with clay/carbonate. According to Katinas (1971), the heavy mineral assemblage is dominated by garnets. The Upper Paleocene on the Sambian Peninsula comprises dark grey and black mudstones. Similar deposits are $11.3 \mathrm{~m}$ thick and were documented in borehole No. 2 drilled in the village of Zaostrovie. These have been defined as the Zaostrovie Formation of Thanetian age (Zagorodnykh et al., 2001).

The Sambian Formation, $\sim 44 \mathrm{~m}$ thick, with its stratotype in the Vistula Spit established by Baltakis in 1966 (fide Grigelis, 1996), is composed of sandy claystones with glauconite and phosphatic concretions. The lowermost part contains fragments of silicified rocks. The transparent heavy mineral assemblage is dominated by epidote (Katinas, 1971). The Sambian Formation contains traces of benthic fossils, diatoms and sponge spicules and is attributed to the Ypresian. According to some authors (e.g., Zagorodnykh et al., 2001), a lithological unconformity is recognized at the top of the Sambian Formation, indicating a possible stratigraphic hiatus.

The Alka Formation established by Grigelis et al. (1971), generally 10-20 m (up to $46 \mathrm{~m}$ ) thick, consists of grey-greenish glauconite-quartz sands with silt intercalations, with quartz and phosphatic gravels at the base. The formation was subdivided into three lower-rank lithological units: Lower Wild Earth, Lower Blue Earth and Lower Quicksand, and attributed to the Bartonian (Zagorodnykh et al., 2001).
The Prussian Formation was established by Baltakis in 1967 (fide Grigelis et al., 1971) within the Primorskiy opencast amber mine in the Yantarny settlement (Fig. 1). The thickness of the formation usually varies from $20-30 \mathrm{~m}$, locally $>40 \mathrm{~m}$. It is subdivided into four informal lithological units: Upper Wild Earth consisting of coarse-grained quartz sands with quartz and phosphate gravels; Upper Blue Earth, developed as sandy and clayey silts/siltstones with glauconite and amber; Upper Quicksand, including a facies referred to as "Krant", composed of fine-grained glauconite-quartz sands with quartz gravels; and "White Wall", composed of finely laminated silt with muscovite and fine amber debris. Deposits of the Upper Wild Earth contain a zircon-epidote heavy mineral assemblage with andalusite, whereas the upper units are dominated by an epidote assemblage (Kosmowska-Ceranowicz et al., 1997). Based on microfaunal data, the age of the formation corresponds to the Late Eocene (Priabonian; Zagorodnykh et al., 2001). Studies by Kosmowska-Ceranowicz et al. (1997) of the Upper Wild Earth and Upper Blue Earth deposits from the Primorskiy opencast amber mine have indicated the presence of dinoflagellate assemblage D12.

Microfaunal remains in the Prussian Formation of the Kaliningrad region are extremely rare and so far no index taxa have been found (Kharin and Lukashina, 2002). Therefore, there are contrasting opinions about the age of this formation, either Mid- to Upper Eocene (Grigelis et al., 1971) or only Upper Eocene (e.g., Alexandrowa and Zaporozhets, 2008a, b). According to Kharin and Lukashina (2002), the age of the Prussian Formation is doubtful, because no microfaunal index species were found there. The first K-Ar datings of glauconite pointed to an age of 35-41 Ma, corresponding to the Bartonian (Kaplan et al., 1977; Zagorodnykh et al., 2001). However, the age of the glauconite from the Blue Earth was significantly earlier, at 44.1 \pm 1.1 and $47.0 \pm 1.5 \mathrm{Ma}$, corresponding to the Lutetian (Ritzkowski, 1997). The latter suggestion seems to contradict the idea that the marine sedimentation in this area was interrupted during the Lutetian (Zagorodnykh et al., 2001).

Oligocene (Rupelian) deposits are represented by the Palveska Formation, which includes the Green Wall unit (Kaplan et al., 1977). This comprises brownish-green and bright green glauconite-quartz sands with a clayey basal horizon. The heavy mineral assemblage is dominated by garnets and epidotes with zircon (Kosmowska-Ceranowicz et al., 1997). The dinoflagellate cyst assemblage corresponds to zones D12/13 (op. cit.). The Chattian part of the Palveska Formation is usually 5-12 m thick (Zagorodnykh et al., 2001) and represents the highest part of the Paleogene succession on the eastern margin of the Gulf of Gdańsk.

A review of previous studies, including the geological setting and stratigraphy, and palaeontological data on dinoflagellate cysts, spore and pollen grains, foraminifers etc., was published by Aleksandrova and Zaporozhets (2008a).

\section{MATERIAL AND METHODS}

The Polish-Russian studies, described here, were made on the Yantarny P-1 core section, drilled in 2001 in the Sambian Peninsula coastal zone (Fig. 1A), and on the exploitation groove samples taken from the eastern slope of the pit in the Primorskiy opencast amber mine (Fig. 1B). The Yantarny P-1 borehole, $75 \mathrm{~m}$ deep, is located on an anthropogenic dump separating the abandoned Plyazhevy amber mine from the open sea. A lithological field description was made directly after 

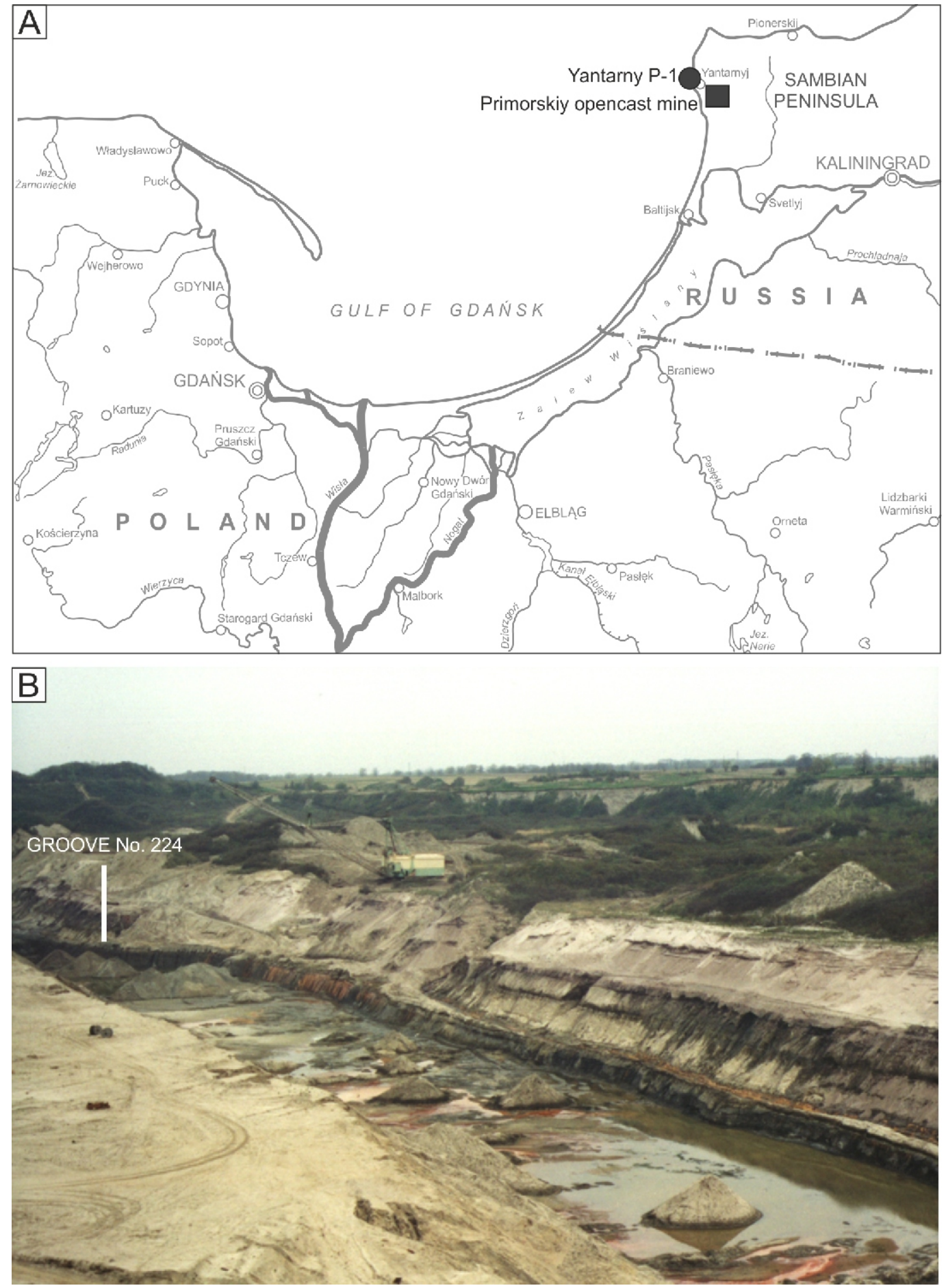

Fig. 1A - location of the Yantarny P-1 borehole and Primorskiy opencast mine $\left(54^{\circ} 52.2^{\prime} \mathrm{N}\right.$; $\left.19^{\circ} 55.9^{\prime} \mathrm{E}\right)$; B - groove No. 224 of the Primorskiy opencast mine

the drilling by Russian (Atlantic Branch of the Shirshov Institute of Oceanology, Kaliningrad) and Polish geologists (see for details Kramarska et al., 2004).

A multidisciplinary study of this section, including detailed lithological analysis, heavy mineral analysis, palynological and micropalaeontological (foraminifers), was carried out by an international group of Polish and Russian geologists.

Lithological characteristics of the deposits (including the grain-size distribution) of 56 sediment samples were determined by the sieve-laser method, after removal of organic matter from the samples using hydrogen peroxide. Samples were separated into fractions in every $\varphi^{1} / 2$, using grain classes according to Wentworth (1922). The carbonate content was defined in 10 samples from the Cretaceous rocks and 56 samples from the Paleogene deposits. The $\mathrm{CO}_{2}$ volume generated after sediment $/ \mathrm{HCl}$ reaction was measured in a Scheibler's calcimeter.

Heavy mineral analyses. Study of heavy minerals from 33 samples was performed on the $0.125-0.063 \mathrm{~mm}$ fraction as only this fraction was present in all lithostratigraphic units. The heavy mineral fractions were separated in an aqueous solution of sodium polytungstate with a density of $2.90 \mathrm{~g} / \mathrm{cm}^{3}$. Up to 300 
transparent grains (all grains in cases of low frequency) were counted in each sample. The percentages were calculated for genetic groups of minerals, and separately for transparent and opaque minerals, as was done previously for the Paleogene deposits in the Gulf of Gdańsk region (e.g., KosmowskaCeranowicz, 1987; Kosmowska-Ceranowicz et al., 1997).

Palynological studies. 58 samples from the Yantarny P-1 borehole and 13 samples from the Primorskiy opencast amber mine were studied palynologically. These samples were collected from a $60 \mathrm{~m}$ thick interval from the depth interval of 9.8-63.9 $\mathrm{m}$ in the Yantarny P-1 borehole and from a 4 m thick interval (14.2-19.0 $\mathrm{m}$ depth) on the eastern slope (exploitation groove No. 224) of the Primorskiy opencast amber mine.

Palynological samples were processed in the laboratory of the Polish Geological Institute - National Research Institute, Marine Geology Branch in Gdańsk. Carbonates were removed with $10 \% \mathrm{HCl}$ and humic acids, using $7 \% \mathrm{KOH}$. Next, the mineral components were eliminated using heavy-liquid separation $\left(\mathrm{CdJ}_{2}+\mathrm{KJ}\right.$; density $\left.2.21 \mathrm{~g} / \mathrm{cm}^{3}\right)$. The samples were sieved on a $10 \mu \mathrm{m}$ nylon mesh. Later, the organic content was processed according to a modified Erdtman's acetolysis method (Moore et al., 1991). Palynological slides were made from each sample, using glycerine as the mounting medium; a full spectrum of palynological material: palynomorphs (sporomorphs, phytoplankton and zoomorphs) and palynoclasts (phytoclasts and mineral debris) was examined.

Dinoflagellate cysts, acritarchs, prasinophytes, green algae, and spore and pollen grains were identified in detail. Each slide was reviewed in order to identify the age-diagnostic index species present in the assemblage. The taxonomy of dinoflagellate cysts follows Williams et al. (2017a, b). Spore and pollen grains were identified using a combined morphological and natural taxonomy (Stuchlik et al., 2001, 2002, 2009, 2014). Palynomorphs were photographed using a Leitz Aristplan microscope coupled with Orthomat $E$ equipment.

\section{MICROFAUNAL ANALYSIS}

Microfaunal studies were carried out on 27 samples from the Yantarny P-1 borehole. Some microfaunal remains foraminifers, diatoms, sponge spicules and fish teeth - were observed in the succession (Olszewska and Garecka in Kramarska et al., 2004; Lukashina, 2010).

\section{RESULTS}

\section{LITHOLOGICAL DESCRIPTION}

The interval of borehole P-1 studied is as follows (from base to top; Fig. 2).

Cretaceous deposits (66.4-75.0 m depth) are represented by marls with intercalations of silicified siltstone. Foraminifers and nanoplankton (Olszewska and Garecka, in Kramarska et al., 2004), and dinoflagellate cysts (Aleksandrova and Zaporozhets, 2008a, b) indicate an Early Campanian age for this part of the succession.

All Paleogene lithostratigraphic units (Lubava, Sambian, Alka and Prussian formations) have been recognized in the Yantarny P-1 borehole section (Fig. 2; Kramarska et al., 2004). In turn, only the Prussian Formation was indicated in exploitation groove No. 224 of the Primorskiy opencast amber mine. The boundaries of the units were established based on lithological features, heavy mineral composition and palynological assemblages.
The Lubava Formation (51.7-66.4 m depth; Fig. 2) is composed of carbonate-free and low-carbonate siltstones with greenish-grey and grey clayey and sandy silts, mostly quartz-glauconitic, occurring at the base of the unit. The deposits are mostly sandy, with silicified, locally bioturbated horizons (Fig. 3A). The silicified horizons are quartz-wackes, generally containing angular pelite to psammite grains. Only a few grains of K-feldspar and plagioclase were observed. Muscovite and biotite flakes, green sponge spicules filled with silica, and iron hydroxides are common. Single granitoid rock fragments and clasts of claystone with glauconite are present. The matrix is basic in character, composed of olive-coloured clay minerals (chlorite?), impregnated with semi-crystalline silica, iron hydroxides, and partly also with pyrite (Maliszewska in Kramarska et al., 2004). There are local concentrations of silica without clay minerals. Decalcifield siltstones occur at the depth of $56.0-57.0 \mathrm{~m}$; their silty and sandy fractions consist of transparent, usually well-rounded quartz grains (with a few milky grains) and a few muscovite flakes. Locally, indistinct horizontal lamination is observed within silty clays. Strongly silicified deposits with bioturbated horizontal lamination, phosphorite nodules and beds of phosphatic sand occur in the upper part of the section. The top of the formation is marked by a hardground with a concentration of phosphates (Fig. 3B).

The Sambian Formation (37.2-51.7 depth) begins with a thin bed of phosphatic-quartz fine gravel occurring above the hardground surface of the Lubava Formation. The upper part of the formation is represented by carbonate-free, quartz sandy silts and silty sands, grey-greenish, dark grey and black in colour, with glauconite admixture, and intercalations and laminae of grey and green clays (Fig. 3C). Quartz grains are wellrounded; evidence of transportation scratches and traces of collision are visible on the surfaces of coarser grains. Very fine glauconite aggregates occur throughout the entire formation; moreover, a small admixture of dispersed muscovite flakes is present at the base of the formation. The distinctly laminated clay and silt deposits are frequently bioturbated. Some burrows of benthic organisms tend to be filled with coarser quartz-glauconitic sand (Fig. 3D). Thin intercalations of black silt, horizontally laminated, occur among these lighter silt-sand sediments. Numerous small core fragments were lithified (Fig. 3E); microscopically they represent quartz-glauconite wackes, composed mainly of angular to subrounded quartz grains, usually $0.15 \mathrm{~mm}$ (up to $0.70 \mathrm{~mm}$ ) in diameter. A few small grains of feldspars, muscovite and green biotite flakes, fragments of crystalline schist, and sponge spicules are present. Cracks in the quartz and feldspar grains are filled with partially recrystallised glauconite. The matrix of the wackes is composed of clay minerals, presumably illite and chlorite, and cryptocrystalline silica. It is locally impregnated with brown iron compounds and contains also fine pyrite nodules.

The Alka Formation (18.5-37.2 m depth) is subdivided into three units (Fig. 2). The lowermost unit, i.e. the Lower Wild Earth Member (35.9-37.2 $\mathrm{m}$ depth, $1.3 \mathrm{~m}$ thick), is represented by very fine-grained, silty quartz sands, faintly laminated horizontally, with lenses of coarse-grained glauconite-quartz sand with fine quartz gravel. The quartz grains (both transparent and dull) are subrounded to rounded but poorly sorted. In the background occur phosphate concretions and scattered milky quartz grains, 3-5 $\mathrm{mm}$ in size. An erosional surface, emphasised by a concentration of quartz grains up to $4 \mathrm{~mm}$ in diameter, is visible at the depth of $36.7 \mathrm{~m}$. Above this there are six simple sedimentary cycles (fining-upward sequences) with a layer of quartz gravel at the base of each cycle; the deposit is highly bioturbated. A thin cemented layer of clayey-siliceous glauconite-quartz sandstone 


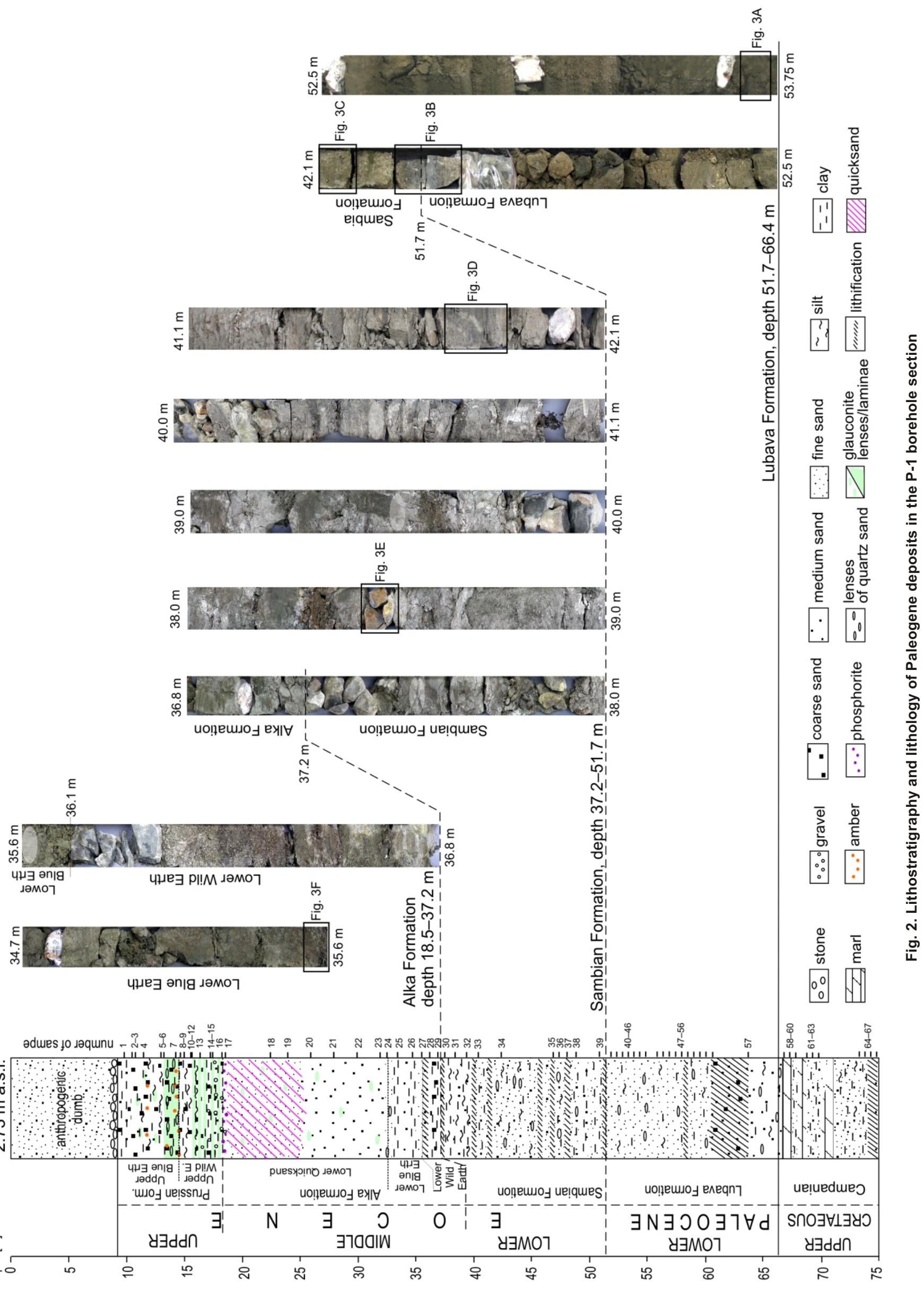



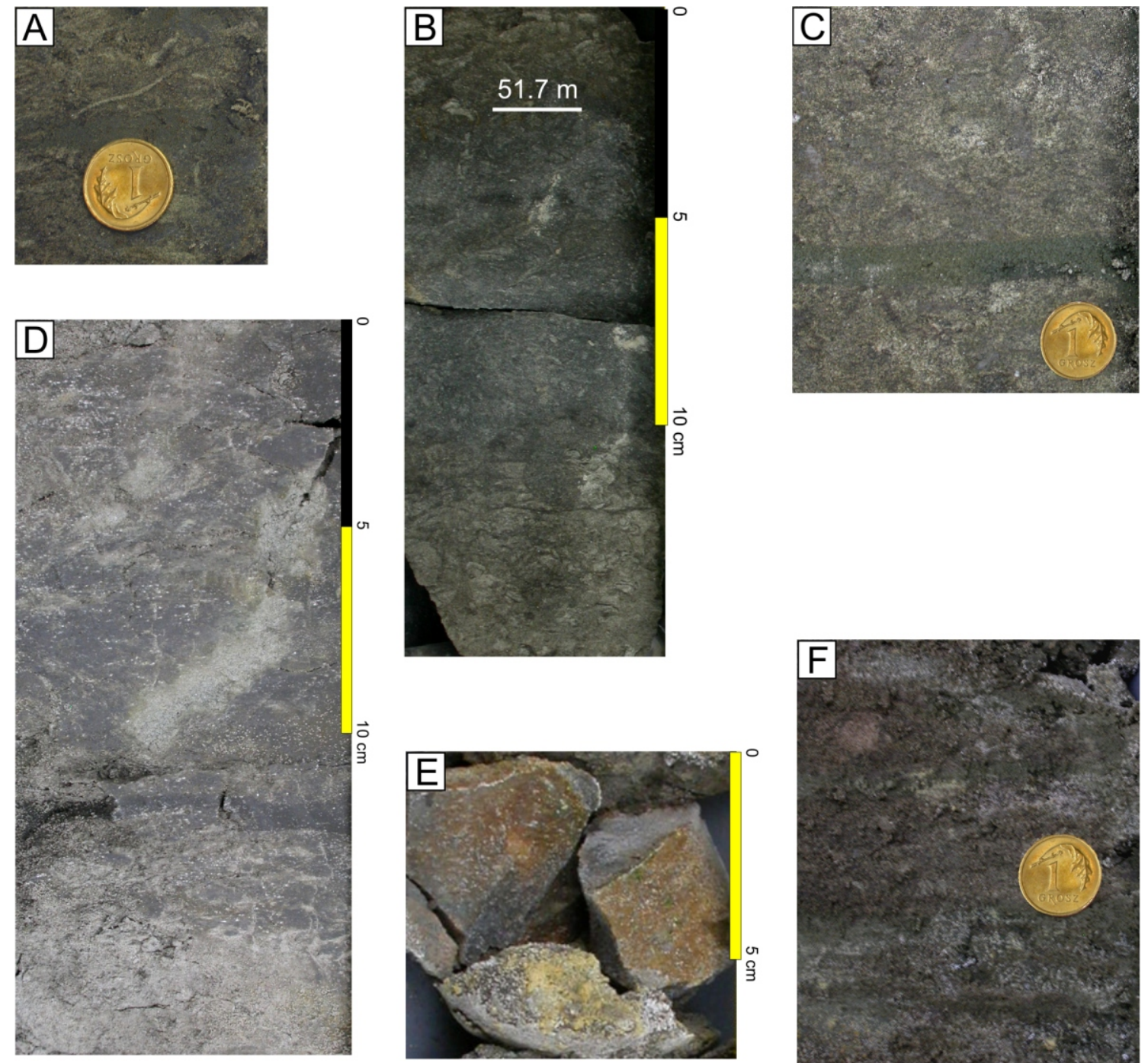

Fig. 3. Lithology of Paleogene deposits in the P-1 borehole section

A - greenish-grey sandy silt with light grey very fine glauconite-quartz sand, biotubated (Paleocene, Lubava Formation, depth $53.6 \mathrm{~m}$ ); B - very fine and silty sand, glauconite-quartz, greenish-grey, strongly bioturbated, a hardground with fine phosphates and quartz (grain size up to $5 \mathrm{~mm}$ ) is visible in the lower part (Paleocene, Lubava Formation, depth $51.7 \mathrm{~m}$ ); C - greenish-grey glauconite-quartz silty sand, strongly bioturbated (Eocene, Sambian Formation, depth 49.2 m); D grey silty clay, bioturbated; large burrows filled with light grey clayey silt, in the top part light grey sandy silt, strongly bioturbated (Eocene, Sambian Formation, depth $41.8 \mathrm{~m}$ ); E - glauconite-quartz wackes - levels of lithification within silty sandy deposits (Eocene, Sambian Formation, depth $38.4 \mathrm{~m}$ ); F - grey-greenish glauconite-quartz sand of variable grain size with green clay intercalations, strongly bioturbated (Eocene, Sambian Formation, depth $35.5 \mathrm{~m}$ )

occurs in the top of the Lower Wild Earth: the sandstone matrix is dominated by clay minerals with cryptocrystalline silica. The Lower Blue Earth Member (32.5-35.9 m depth), >3.4 m thick, is composed of greenish-grey glauconite-quartz sand of variable grain size. Very fine-grained and silty sands with thin green clay intercalations prevail in the lower part of this interval (Fig. 3F). Quartz grains are subrounded to rounded but poorly sorted; scratches, traces of collision and corrosional bays are visible on the surfaces of coarser particles. The sediment was primarily horizontally laminated, but the lamination has been strongly disturbed by extensive bioturbation. The Lower Quicksand Member, 14.9 m thick, occurs between $18.5-32.5 \mathrm{~m}$ b.s.l. It consists of grey-greenish quartz sands of variable grain size with glauconite admixture and thin intercalations of sandy silt. Quartz grains (mostly transparent) belong to two populations: coarser grains are well-rounded and finer grains (very fine fraction) are more angular. Surface scratches, traces of collision and corrosion bays are visible on the coarser particles. Strongly bioturbated layers occur also in the Lower Quicksand Member.

The Prussian Formation (9.3-18.5 m depth; Fig. 2) is represented by two units. (1) The lowermost unit is known as the Upper Wild Earth Member, $3.7 \mathrm{~m}$ thick. It consists of horizontally laminated heterolithic deposits comprising glauconite-quartz sands and sandy silts with an admixture of glauconite and muscovite, locally with quartz and phosphate gravels. In the bottom part of the unit, an erosional surface occurs at the top of one of the silty sand beds. Quartz grains (mostly transparent ones) are usually well-rounded, and some scratches and traces of collision are visible on the surfaces of coarser grains. Some dispersed fragments of amber, $1-10 \mathrm{~mm}$ in size, occur in this unit. (2) The 
Upper Blue Earth Member, up to $5.5 \mathrm{~m}$ thick (9.3-14.8 m depth) is composed of blue-greenish silty sands with intercalations of light grey fine-grained quartz sand, and dark blue and black silty clays with frequent amber grains (grain size $\sim 7 \mathrm{~mm}$, up to $30 \times 20 \times 5 \mathrm{~mm}$ ). Quartz grains (milky and transparent ones) representing finer fractions are well-rounded and the coarser fractions are usually poorly rounded; the surfaces of many grains show collision traces. These deposits contain a significant admixture of muscovite, aggregates of glauconite and individual sandstone lithoclasts. Coaly clay laminae and concentrations of coalified plant detritus also occur.

Deposits of the Prussian Formation (Upper Blue Earth Member) are recognized also in the exploitation groove sample No. 224 taken from the Primorskiy opencast amber mine in the interval 14.2-19.0 $\mathrm{m}$ b.s.l. They include glauconitic, brown-greenish silts with a varying admixture of sand. Sandy mudstones occur in the interval of 18.7-19 m b.s.l. (in the bottom of the exploitation groove), with a thin level of phosphatic nodules and dispersed, well-rounded quartz grains at the base. Several bioturbated horizons, related probably to the activity of mud-eaters, were noted within 16.7-18.7 $\mathrm{m}$ b.s.l. At the level of $15.8 \mathrm{~m}$ b.s.l. there is a horizon with dispersed fine-gravel quartz grains. In the upper part of the section (depth interval $14.2-15.3 \mathrm{~m}$ ) there are several intercalations of glauconitequartz sand.

\section{GRAIN-SIZE COMPOSITION AND HEAVY MINERAL ASSOCIATIONS}

Yantarny P-1. A variable grain-size composition and assemblages of heavy minerals have been distinguished within the Paleogene deposits from the Yantarny P-1 borehole section (Fig. 4).

The lower part of the section, corresponding to the Lubava Formation (51.7-66.4 m depth) is dominated by very fine clastic deposits, composed mostly of silty clays with an admixture of very fine-grained sand. The maximum particle size is $0.125 \mathrm{~mm}$. Chlorite flakes, characteristic of the silty-sandy facies, represents 10 to $>70 \%$ of the total mineral composition Noteworthy is also the high content of glauconite, aggregates of which show no traces of chemical weathering and transformation. This mineral comprises on average $39.4 \%$ of the total heavy minerals $(14.7-57.7 \%)$. The content of opaque minerals rarely exceeds $10 \%$, whereas the contribution of transparent minerals usually reaches several percent. The percentage of minerals representing both groups slightly increases in the upper part of the section. Moreover, infrequent siderite fragments occur there, which indicates poor sorting. The content of poorly-resistant minerals, represented mainly by amphiboles (mostly greenish hornblende), varies from $16-54 \%$ (averagely $29.2 \%$ ). These are accompanied by pyroxenes reaching up to $1.0-8.5 \%$. There is also a considerable amount of biotite (at only two levels: 38.7 and $25.0 \%$ ) in this part of the section. The epidote content varies from $\sim 10-20 \%$ of total transparent minerals (average 13.7\%). The content of garnets is from $5.0-17.6 \%$ (averagely $10.0 \%$ ). Tourmaline, with a contribution from $6.0-15.3 \%$, slightly dominates among the resistant minerals. In the lower part of the formation, the disthene content $(8.5-12.0 \%)$ is similar, decreasing to $4 \%$ in the upper part. The zircon content is low, usually $\sim 1 \%$, to reach $>5 \%$ only in the middle part of the formation.

In the upper part of the P-1 borehole section, from the depth of $51.7 \mathrm{~m}$ to the top of the Eocene deposits, an epidote association of heavy minerals was defined, locally with an increasing content of resistant minerals, particularly zircon and disthene. The lower part of this interval, corresponding to the Sambian Formation, is represented in the bottom and top parts by silty sands and in the middle part by clayey sandy silts. The lowermost part of this formation $(51.4-47.0 \mathrm{~m})$ is dominated by fine-grained sands with a small amount of coarse sand and gravel. Its middle part is characterized by a prevalence of silty clay with $\sim 25 \%$ of very fine-grained sands. The top of the formation is again dominated by fine-grained sand (50-65\%) but without coarse sands and gravels.

In contrast to the Lubava Formation, the Sambian Formation contains an increased share of opaque minerals in relation to transparent minerals. The content of other minerals is lower (there is a small admixture of glauconite, and chlorite occurs only sporadically). The maximum content of ore minerals $(>50 \%)$ within the total amount of heavy minerals was noted in the lowermost part of the formation, where small phosphate concretions are also present. The glauconite content is the lowest in this part of the succession (a few percent), to rise higher upsection (>40\%; average $19.2 \%$ ). In clayey sandy silt the content of chlorite is low, and rare siderite and calcite grains occur. The average content of transparent minerals is $\sim 45 \%$. The lower part of the formation is dominated by an epidote-zircon mineral association. The content of these two mineral groups is subequal - the epidote content is $\sim 30 \%$ and the zircon content is $20-30 \%$. Tourmaline and epidote dominate in the upper part of the section, reaching up to $60 \%$ of the total heavy minerals. Locally, an admixture of biotite is clearly visible. The distribution of other components is relatively even and does not show large fluctuations, except for staurolite and tourmaline, the content of which in the central part of the formation increases to several percent.

The upper part of the borehole section corresponds to the Alka Formation. Deposits of the Lower Wild Earth and the lower part of the Lower Blue Earth members have a silt/clay content of $\sim 15-35 \%$. Grain fractions $0.125-0.063 \mathrm{~mm}$ and $0.25-0.125 \mathrm{~mm}$ predominate within the total sand fraction. A high content (up to $\sim 55 \%$ ) of coarser particles with diameters at $1-2 \mathrm{~mm}$ was noted locally. The composition of heavy minerals from the lower part of the Alka Formation is very similar to that from the upper part of the Sambian Formation, both with respect to the mineral groups and the transparent mineral association.

A monotonous series of sands of variable grain size with a predominant fraction of $0.5-0.25 \mathrm{~mm}$, reaching up to $40 \%$, builds the upper part of the Alka Formation. It corresponds to the Lower Quicksand Member. A coarse fraction admixture, from a few percent to $\sim 20 \%$, increases upwards in the succession. The content of the $0.25-0.125 \mathrm{~mm}$ fraction fluctuates from $\sim 20 \%$ up to $>30 \%$. The $0.125-0.063 \mathrm{~mm}$ fraction constitutes a few percent. The content of the silt-clay fraction $(<0.063 \mathrm{~mm})$ rarely exceeds $15 \%$. The mineral composition is dominated by the carbonate group (36.6-72.3\%), mainly siderite and individual rhombohedral calcite crystals, which is reflected in a slightly higher carbonate content in the Lower Quicksand Member compared with the other parts of the succession. The content of $\mathrm{CaCO}_{3}$ varies from 1.23 up to $4.10 \%$, and is significantly higher than in other units, where it is $<1 \%$. In relation to the lower units of the Alka Formation, in the group of transparent minerals, the Lower Quicksand Member is characterized by a decrease of the epidote content (average $20 \%$ ), an increase of disthene and zircon, and also of staurolite in the uppermost part of the formation.

The grain size distribution of the uppermost deposits in the borehole, representing the Prussian Formation (Upper Wild Earth and the Upper Blue Earth members), records several sedimentary cycles. Medium and coarse sand fractions dominate in the lower part of each cycle and while the silt-clay fractions build their upper parts. This part of the section is characterized by the maximum content of epidote, from $44-70 \%$ (av- 


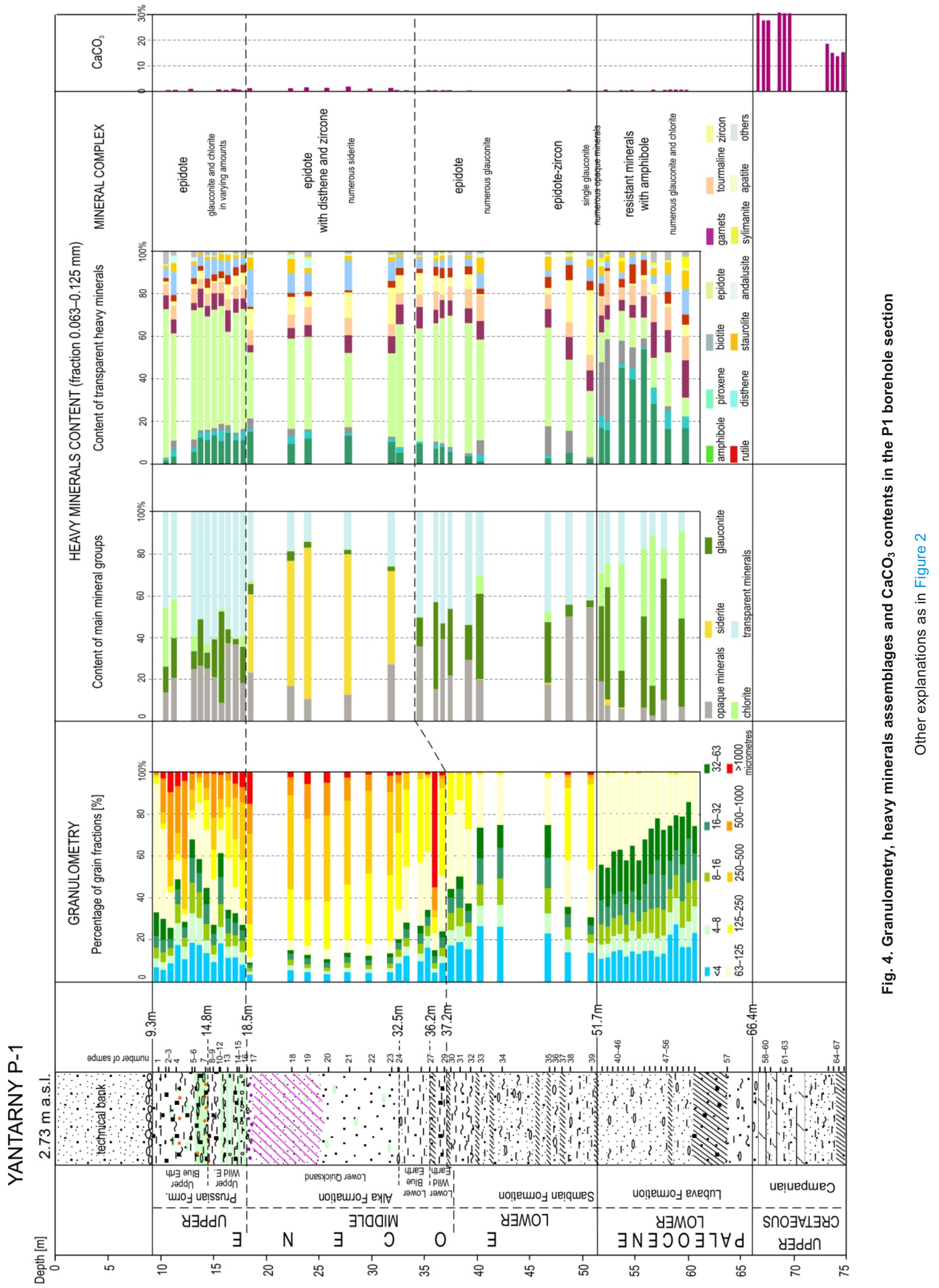


erage $55.7 \%$ ), and the lowest content of resistant minerals. Deposits of the Upper Wild Earth Member contain an increasing panied by a low content of pyroxene.

Primorskiy opencast amber mine - exploitation groove minerals in the deposits examined in exploitation groove No. 224 are very similar to those from the upper part of the P-1 section, corresponding to the Prussian Formation (Fig. 5). Deposits from the exploitation groove represent a silty sand lithofacies with a slight predominance of the sand fraction in the lower and upper parts, and of silt and clay in the middle part. Transparent minerals (42.9-64.3\%) predominate among the heavy minerals. The contribution of opaque minerals, usually at $26-29 \%$, is fairly even. The glauconite content is variable $(5.0-24.3 \%)$. The chlorite content reaches a maximum of $2.6 \%$ in the lower part of the pit and exceeds $5 \%$ in its higher part. The carbonate content is $2-4 \%$ in the lower part of the pit.

Transparent minerals are represented by the epidote association, as in the upper part of the P-1 borehole section. The epidote association (mainly epidote sensu stricto, rarely zoisite and clinozoisite) comprises $49.7-57.7 \%$ of total transparent minerals. The content of garnets occasionally exceeds $10 \%$, and the content of amphiboles together with pyroxenes is similar. The content of resistant minerals reaches $20-30 \%$.

\section{PALYNOLOGY}

Palynofloral assemblages in the samples are rich, diverse and well-preserved. They are dominated by dinoflagellate cysts, while spores and pollen grains are scarce in most of the Paleocene-Eocene samples. In total, 161 phytoplankton and 143 sporomorph taxa have been recognized in the succession studied. The stratigraphic distribution of dinoflagellate cyst taxa is shown in the Appendix $1^{*}$. The most characteristic taxa are illustrated in Figures 6-12. Phytoclasts, represented by brown and black wood fragments and cuticule, were also observed. Foraminiferal organic linings also occur. Single glauconitic aggregates were noted among the inorganic components.

Five successive palynological assemblages were recognized within the interval of the Yantarny P-1 borehole studied, from base to top.

Yantarny P-1. Palynomorph assemblage from the lowest part of the Paleogene in the Yantarny P-1 borehole section (52.0-67.0 m depth) is dominated by marine phytoplankton. The lowermost part of the Paleogene section of the Yantarny P-1 borehole section (Lubava Formation) yields a pollen-phytoplankton spectrum indicative of the Selandian (Middle Paleocene; Słodkowska, 2008). The presence of Alisocysta margarita, Alterbidinium circulum, Fibradinium annetorpense, Isabelidinium viborgense, Palaeotetradinium minusculum, $P$. silicorum and Spinidinium densispinatum allows attribution of this part of the section to the dinoflagellate cyst zones D3-D4 (Powell, 1992; Köthe, 2012), indicating a mid-Paleocene (Selandian) age (Table 1; Figs. 6-8 and 12). The occurrence of Cretaceous dinoflagellate cysts Isabelidinium bujaki, I. cooksonii, Odontochitina sp. and Senoniasphaera rotundata in the same assemblage suggests their reworking from Cretaceous strata. The mid Paleocene age is additionally confirmed by the presence of the Normapolles group pollen grains, in particular Pompeckjoidaepollenites platoides, Oculopollis baculotrudens and Trudopollis classotrudens.

Abundant and well-preserved marine palynomorphs were found at 36.3-51.0 m depth in the Sambian Formation. The palynological assemblage from the Sambian Formation conadmixture of amphiboles (mostly greenish hornblende), accomNo. 224. The grain-size composition and the content of heavy

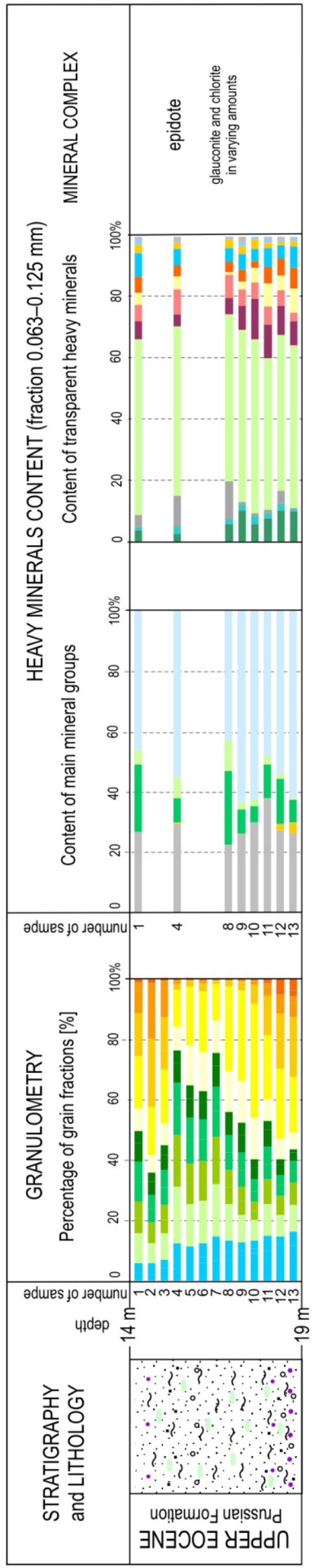

* Supplementary data associated with this article can be found, in the online version, at doi: $10.7306 /$ gq.1513 

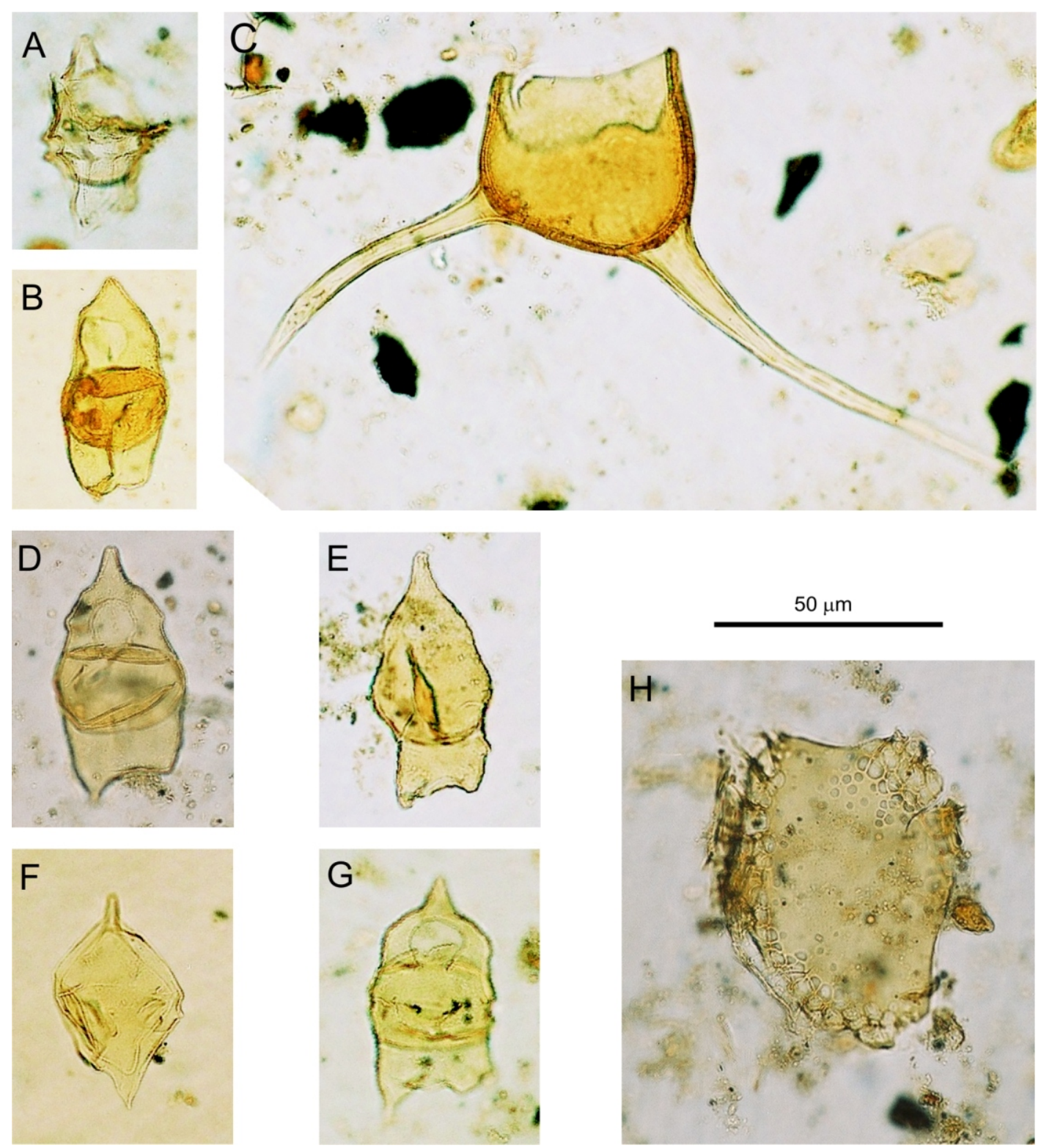

Fig. 6. Cretaceous taxa - reworked

A - Spinidinium clavum Harland 1973, Yantarny P-1, depth 59.0 m; B - Isabelidinium bujakii Marheinecke, 1992; C - Odontochitina sp., Yantarny P-1, depth 57.0 m; D, E - Isabelidinium cooksoniae (Alberti, 1959) Lentin \& Williams, 1977, Yantarny P-1, depth $59.0 \mathrm{~m}$ (D) and $58.0 \mathrm{~m}$ (E); F - Laciniadinium sp., Yantarny P-1, depth $54.0 \mathrm{~m}$; G Chattangiella cf. tripartita (Cookson \& Eisenack, 1960) Lentin \& Williams, 1976, Yantarny P-1, depth 53.5 m; H Senoniasphaera rotundata Clarke \& Verdier, 1967, Yantarny P-1, depth $56.5 \mathrm{~m}$

tains stratigraphically important dinoflagellate cysts Eatoniacysta ursulae, Deflandrea oebisfeldensis, Hystrichosphaeridium tubiferum and Rottnestia borussica, indicating an Early Eocene (Ypressian) age. The taxonomic composition of this assemblage is similar to that of zone D7 (Powell, 1992; Köthe, 2012) of Ypresian age. Among the continental palynomorphs, the pollen grains of thermophilous plants and fairly abundant pollen from the Normapolles group, especially Extratriporopollenites clarus, Pompeckjoidaepollenites peneperfectus, Trudopollis cf. bulboformis and T. ordinatus, are noted (Table 1 and Fig. 9). Phytoclasts are sparse; foraminifer linings were observed in all samples.

In the upper part of the borehole section, Alka Formation (depth 18.6-35.6 m), a rich but not very diagnostic palynomorph assemblage was found (Table 1): marine paly- nomorphs are represented by taxa with a broad stratigraphic range: Corrudinium incompositum, and other taxa, such as Cordosphaeridium fibrospinosum, C. funiculatum, Phthanoperidiunium crenulatum, Lingulodinium machaerophorum and Charlesdowniea sp. Reworked taxa from older Paleocene assemblages were also present. Pollen grains were infrequent, among them single Normapolles grains appeared. Phytoclasts and foraminifer linings were rare; single glauconite aggregates also occurred. This assemblage is tentatively attributed to the dinoflagellate cyst Zone D9 (Powell, 1992; Köthe, 2012) of Lutetian age.

An abundant and diverse dinoflagellate cyst assemblage was recognized in the Prussian Formation (9.8-18.3 m depth), containing the stratigraphically important species Areosphaeridium michoudii, A. diktyoplokum, Cerebrocysta bartonensis, 

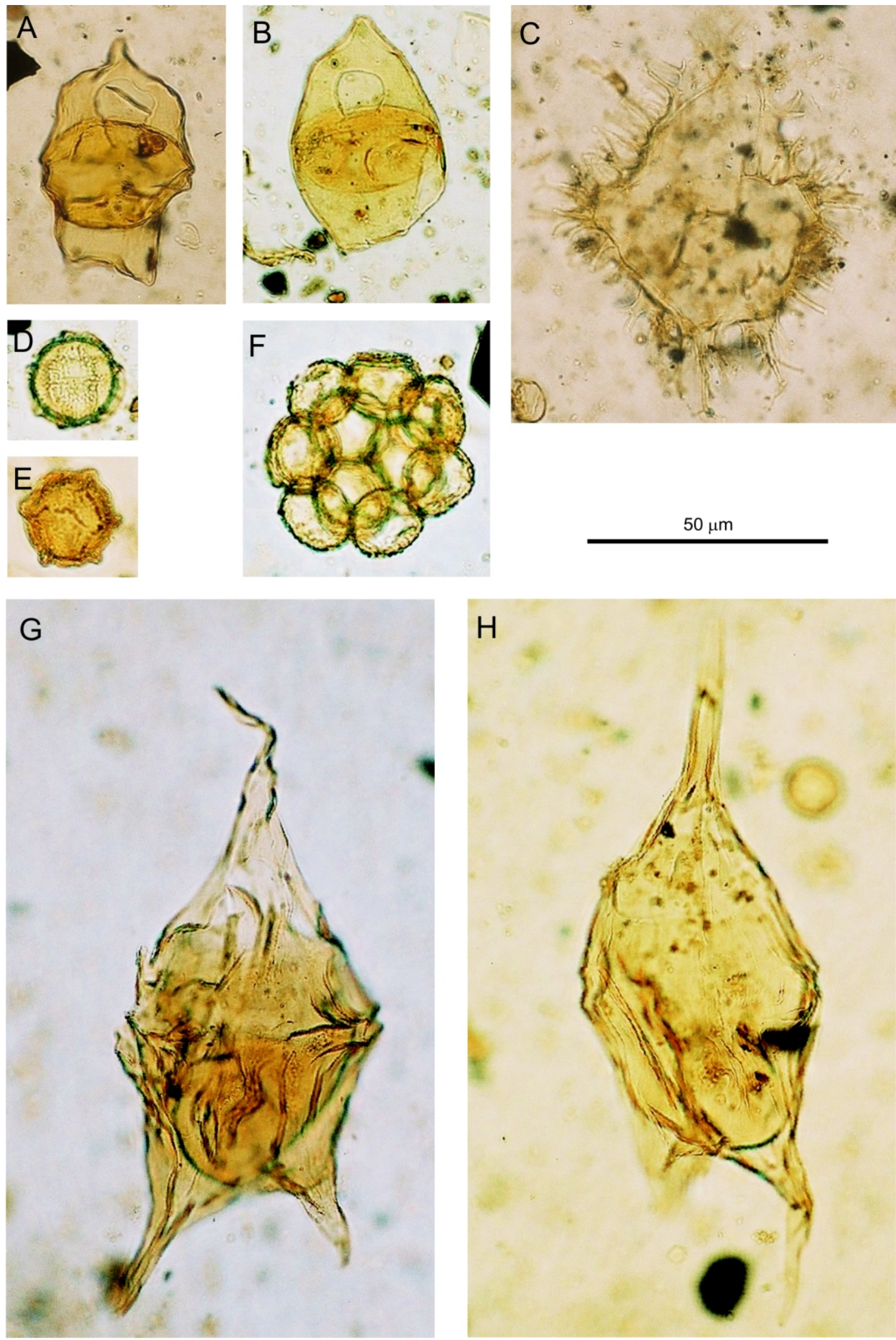

Fig. 7. Phytoplankton assemblage - Middle Paleocene (Selandian)

A - Chattangiella sp., Yantarny P-1, depth 56.0 m; B - Alterbidinium circulum (Heilman-Clausen, 1985) Lentin \& Williams, 1989, Yantarny P-1, depth 60.0 m; C - Apectodinium hyperacanthum (Cookson \& Eisenack, 1965) Lentin \& Williams, 1977, Yantarny P-1, depth 60.0 m; D, E - Fibradinium annetorpense Morgenroth, 1968, Yantarny P-1, depth $56.0 \mathrm{~m}$ (D) and $56.5 \mathrm{~m}$ (E); F - Palambages morulosa Wetzel, 1961, Yantarny P-1, depth $55.0 \mathrm{~m} ; \mathbf{G}, \mathbf{H}-$ Cerodinium diebelii (Alberti, 1959) Lentin \& Williams, 1987, Yantarny P-1, depth depth $56.0 \mathrm{~m}(\mathrm{G})$ and $59.0 \mathrm{~m}(\mathrm{H})$ 

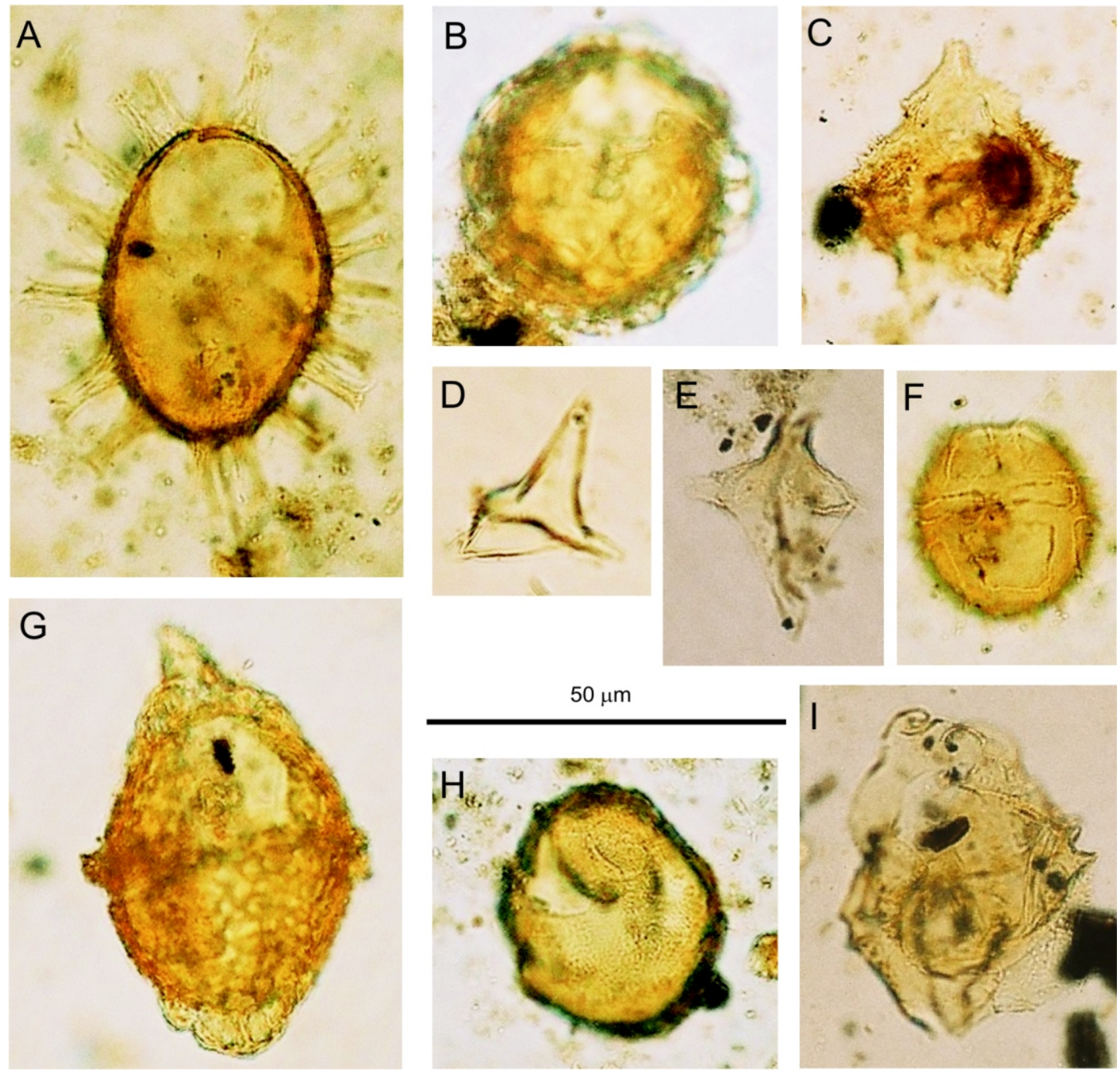

Fig. 8. Phytoplankton assemblage - Middle Paleocene (Selandian)

A - Fibrocysta ovalis (Hansen, 1977) Lentin \& Williams, 1981, Yantarny P-1, depth 67.0 m; B - Samlandia sp., Yantarny P-1 depth 53.5 m; C - Spinidinium echinoideum (Cookson \& Eisenack, 1960) Lentin \& Williams, 1976 , Yantarny P-1, depth 67.0 m; D - Palaeotetradinium silicorum (Deflandre 1936) Deflandre \& Sarjeant, 1970, Yantarny P-1 depth 58.0 m; E - Palaeotetradinium minusculum (Alberti, 1961) Stover \& Evitt, 1978, Yantarny P-1, depth 57.0 m; F - Alisocysta margarita (Harland, 1979) Harland, 1979, Yantarny P-1, depth 67.0 m; G - Damassadinium californicum (Drugg, 1967) Fensome et al,. 1993, Yantarny P-1, depth 54.0 m; H - Caligodinium aceras (Manum \& Cookson, 1964) Lentin \& Williams, 1973, Yantarny P-1, depth 59.0 m; I - Isabelidinium ? viborgense Heilmann-Clausen, 1985, Yantarny P-1, depth 60.0 m

Talladinium? clathratum, Charlesdowniea coleotrypha, Cordosphaeridium funiculatum, Deflandrea heterophlycta, Glaphyrocysta texta, Heteraulcacysta porosa, Cordosphaeridium funiculatum, Deflandrea heterophlycta, Enneadocysta pectiniformis, Glaphyrocysta semitecta, Thalassiphora fenestrata and Rhombodinium porosum (Table 1 and Figs. 10-12). Reworked pollen grains from the Paleocene were also found. The pollen grains were not very frequent and the Normapolles group was represented by a few damaged specimens. Phytoclasts were sparse, and organic foraminifer linings were quite frequent. Based on the presence of Rhombodinium porosum, the lower part the Prussian Formation (10.8-18.3 m depth) is referred to the dinoflagellate cyst Zone D11 (Powell, 1992; Köthe, 2012) of Bartonian age. The palynomorph assemblage from the uppermost part of the borehole section (9.8-10.5 m depth), is generally similar to the underlying one
(Table 1; Figs. 11 and 12). Phytoplankton are very common and include Thalassiphora fenestrata which more often occurs in the Priabonian. Among the rather infrequent spores and pollen grains, pollen of thermophilous plants play an important role. Phytoclasts, organic foraminifer linings and glauconite aggregates are rather rare. This community may probably be attributed to the Upper Eocene (Priabonian) dinoflagellate cyst Zone D12.

Primorskiy opencast amber mine - exploitation groove No. 224. (14.2-19.0 m b.s.l.). The palynological assemblage is dominated by dinoflagellate cysts and contains such species as Areosphaeridium diktyoplokum, A. michoudii, Charlesdowniea clathrata, Cordosphaeridium funiculatum, Deflandrea heterophlycta, Enneadocysta pectiniformis, Glaphyrocysta semitecta, G. texta, Hetraulacacysta porosa, Microdinium reticulatum, Paucilobimorpha incurvata, Pterospermella helios, 

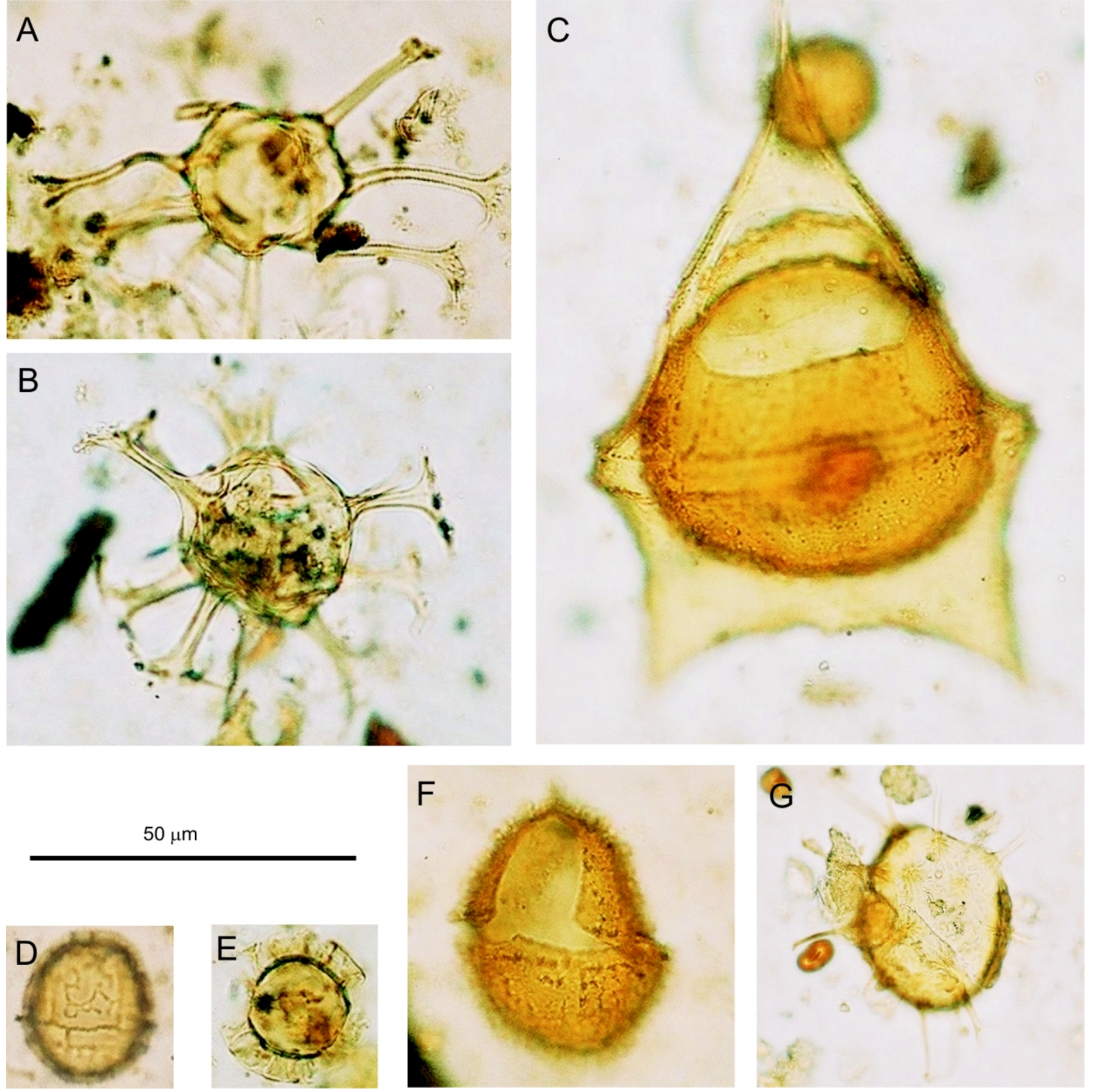

Fig. 9. Phytoplankton assemblage - Lower Eocene (Ypresian)

A, B - Hystrichosphaeridium tubiferum (Ehrenberg, 1838) Deflandre 1937, emend. Davey \& Williams 1966, Yantarny P-1, depth $40.5 \mathrm{~m}(\mathrm{~A})$ and $49.0 \mathrm{~m}$ (B); C - Deflandrea oebisfeldensis Alberti, 1959, Yantarny P-1 depth $59.0 \mathrm{~m}$, Yantarny P-1, depth $40.5 \mathrm{~m}$; D - Corrudinium incompositum (Drugg, 1970) Stover \& Evitt, 1978, Yantarny P-1, depth $51.0 \mathrm{~m}$; E - Cordosphaeridium minimum (Morgenroth, 1966) Benedek 1972, Yantarny P-1 depth 48.2 m; F - Kallosphaeridium sp., Yantarny P-1, depth 51.0 m; G Cordosphaeridium funiculatum Morgenroth, 1966, Yantarny P-1, depth $40.5 \mathrm{~m}$

Rhombodinium porosum and Rottnestia borussica. It is similar to that of the Prussian Formation in the borehole P-1 (D11-D12 Zone interval), indicating the Bartonian and probably Priabonian age of these deposits. Continental palynomorphs are not abundant, but are represented by different thermophilous taxa: Araliaceoipollenites euphorii, Castaneoideaepollis pusillus, Engelhardtioipollenites punctatus, Fususpollenites fusus, Intratriporopollenites insculptus, Monocolpopollenites, Platanipollis ipelensis, Quercoidites microhenrici, Sapotaceoideaepollenites, Tricolporopollenites megaexactus, $T$. liblarensis, $T$. pseudocingulum and T. staresedloensis (Table 2; Figs. 10 and 11). A few phytoclasts, several organic foraminifer linings and numerous glauconitic aggregates were also noted (Fig. 12).

\section{MICROFAUNAL ANALYSIS}

Microfaunal remains, mostly glauconitised fragments of the Nodosariide, silicified sponge spicules and radiolarians are rare in the Paleogene deposits. A few redeposited Upper Cretaceous foraminifers representing Eponides cf. grodnoensis Akimetz and Osangularia cf. cordieriana d'Orbigny were found in the interval $57.5-36.3 \mathrm{~m}$ in the $\mathrm{P}-1$ borehole section (Olszewska and Garecka in Kramarska et al., 2004). Numerous radiolarians, especially representing the genus Spumellaria, occur at a depth of $57.5 \mathrm{~m}$ b.s.l.

In the interval of 52.0-67.0 m depth (Lubava Formation), microfaunal remains were observed only in the uppermost part. Diatoms, siliceous sponge spicules, small bones and fish teeth 

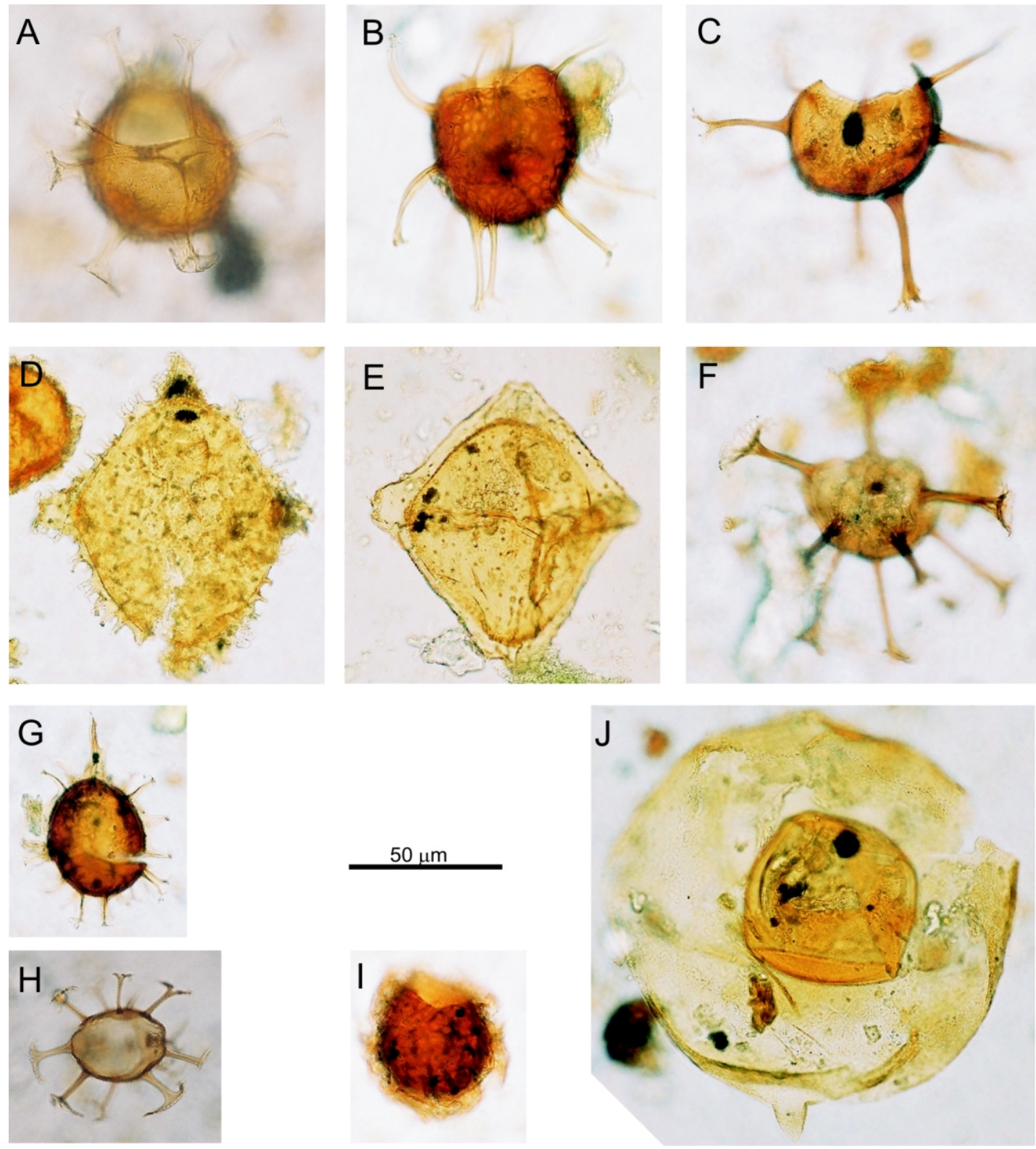

Fig. 10. Phytoplankton assemblage - Middle Eocene (Bartonian)

A - Spiniferites pseudofurcatus (Klumpp, 1953) Sarjeant, 1970, Yantarny P-1 depth 17.5 m; B - Cordosphaeridium funiculatum Morgenroth, 1966, groove No. 224, depth 14.17-14.42 m; C - Cordosphaeridium gracile (Eisenack, 1954) Davey \& Williams, 1971, groove No. 224, depth 15.81-16.21 m; D - Wetzeliella simplex (Bujak, 1979) Lentin and Vozzhennikova, 1989, groove No. 224, depth 15.30-15.81 m; E - Rhombodinium porosum Bujak, 1979, Yantarny P-1 depth 14,7 m; F - Areosphaeridium diktyoplokum (Klumpp, 1953) Eaton, 1971, Yantarny P-1 depth 14.3 m; G - Spiniferella cornuta (Gerlach, 1961) Stover \& Hardenbol 1994, Yantarny P-1, depth 15.6 m; H Enneadocysta pectiniformis (Gerlach, 1961) Stover \& Williams, 1995, Yantarny P-1, depth 15.6 m; I - Samlandia cf. chlamydophora Eisenack 1954, groove No. 224, depth 18.68-18.88 m; J - Thalassiphora pelagica (Eisenack 1954) Eisenack \& Gocht 1960, Yantarny P-1 depth 13.0 m

were found at 52.0-60.8 $\mathrm{m}$ depth. A few poorly preserved foraminifers of the genera Anomalina and Psammosphera occur at depth $60.8 \mathrm{~m}$ (Lukashina in Kramarska et al., 2004). A single redeposited test of the planktonic foraminifer Globigerinella aspera was noted at $60.0 \mathrm{~m}$ depth.

A few agglutinated foraminifers of the family Ammodisciadae with siliceous test walls, such as Ammodiscus sp., Glomospirella sp. and Glomospira sp. were found at 37.0-52.0 m depth (Sambian Formation). Some planktonic cal- careous foraminifers Tappanina selmensis (Cushm.), Bolivina $\mathrm{sp}$. and Globigerinella micra (Cole) were also recognized here.

At 18.5-37.2 m depth (Alka Formation), six planktonic foraminifer taxa were found: Globigerina danvillensis, G. praebulloides, G. eocaena, G. sp. and Acarinina rotundimarginata at $20.6 \mathrm{~m}$ depth, attributed to the planktonic foraminifera zones PF12-PF14 (Lukashina, 2010).

The uppermost deposits of the Alka and Prussian formations yielded no microfaunal remains. 

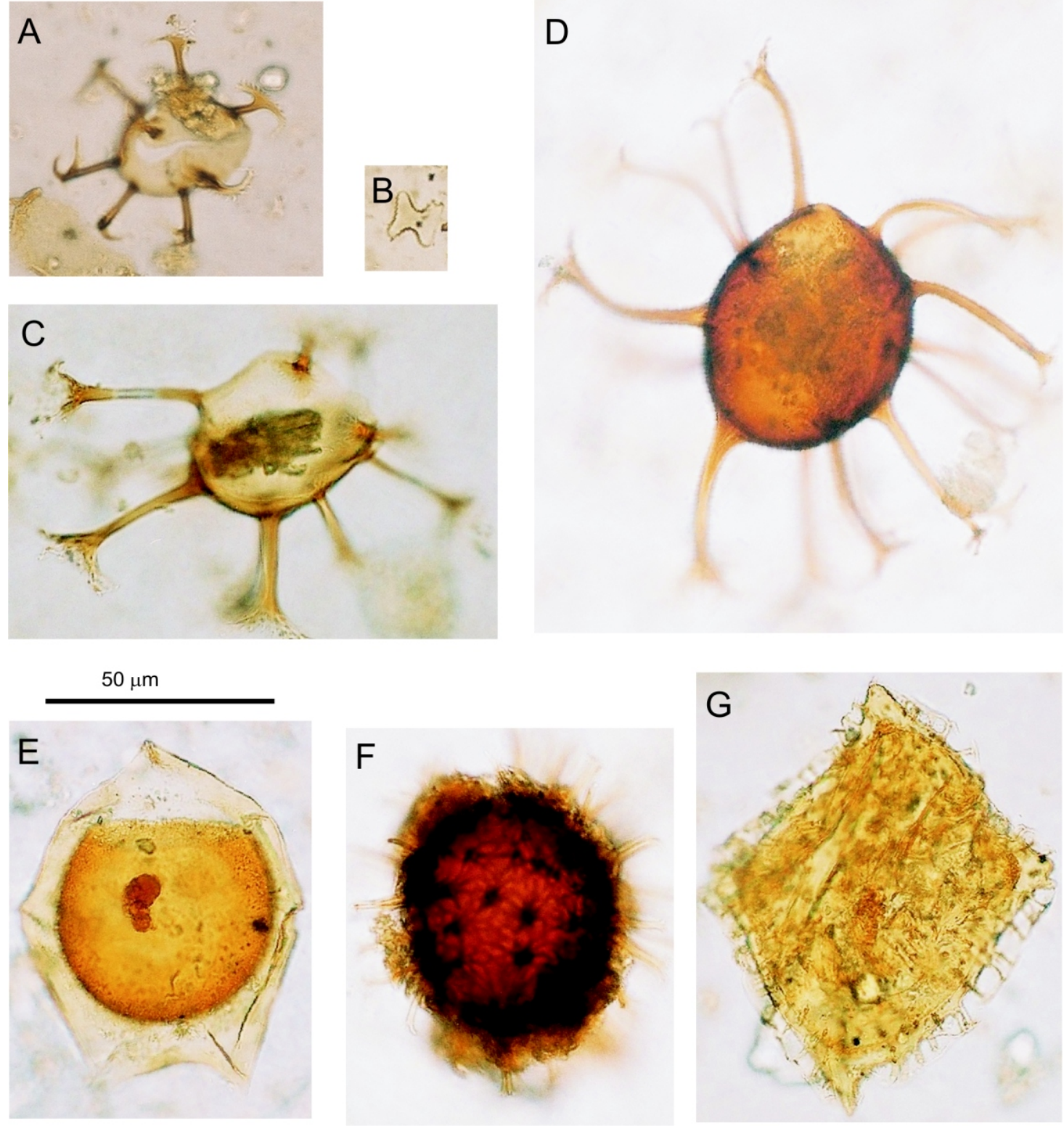

Fig. 11. Phytoplankton assemblage - Upper Eocene (Priabonian)

A - Enneadocysta pectiniformis (Gerlach, 1961) Stover \& Williams, 1995, groove No. 224, depth 16.21-16.71 m; B Paucilobimorpha incurvata (Cookson \& Eisenack, 1962) Prösl, 1994, Yantarny P-1, depth 15.7 m; C Areosphaeridium michoudii Bujak, 1994, groove No. 224, depth 18.34-18.68 m; D - Cordosphaeridium gracile (Eisenack 1954) Davey \& Williams 1966, groove No. 224, depth 18.68-18.88 m; E - Deflandrea phosphoritica Eisenack, 1938, groove No. 224, depth 18.68-18.88 m; F - Cordosphaeridium funiculatum Morgenroth, 1966 , Yantarny P-1, depth 13.3 m; G - Talladinium?clathratum (Eisenack, 1938b, p.187; text-fig.5) Williams, Damassa, Fensome and Guerstein in Fensome et al., 2009, Yantarny P-1, depth $13.3 \mathrm{~m}$

\section{DISCUSSION}

The interval of 51.7-66.4 m depth in the Yantarny P-1 borehole section has previously been attributed to the Maastrichtian Chattangiella vnigrii and Cerodinium diebelii dinoflagellate cyst zones (Aleksandrova and Zaporozhets, 2008a, b).

Based on our palynological results, we do not agree with this opinion, evidencing the presence of phytoplankton species characteristic of the mid-Paleocene: Alisocysta margarita, Fibradinium annetorpense, Isabelidinium viborgense, Palaeotetradinium minusculum, $P$. silicorum and Spinidinium densispinatum. These species occur in situ, ac- companied by Cretaceous phytoplankton taxa and Upper Cretaceous foraminifers that were redeposited from older sediments (Olszewska and Garecka in Kramarska et al., 2004; Lukashina, in Kramarska et al., 2004). The dinoflagellate assemblage from the Lubava Fm. (Yantarny P-1 borehole, 51.7-66.4 m depth) corresponds to the D3-lower D4 zones interval (Köthe, 2012), indicating a Selandian age. The Paleogene age of the Lubava Formation was earlier suggested by Kaplan et al. (1977). The pollen assemblage within this interval is characterized by a large content of palaeotropical taxa. A similar palynomorph assemblage has been recognized in deposits from other parts of the Kaliningrad District (bore- 

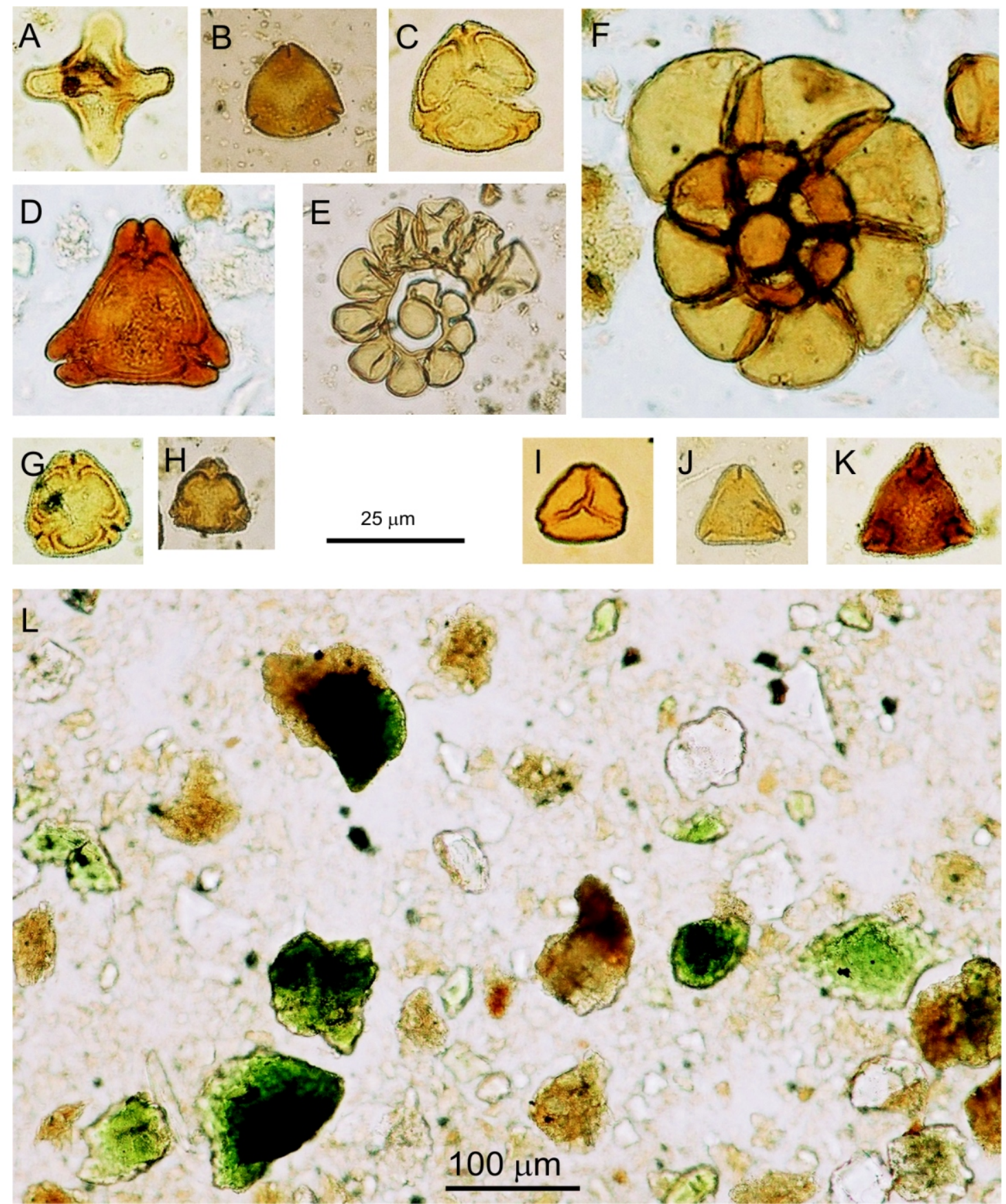

Fig. 12. Sporomorphs, zoomorphs and non-organic remains from the Paleogene deposits

A - Pentapollenites sp. Krutzsch, 1958, Yantarny P-1, depth 59.5 m; B - Pseudoculopollis sp., Yantarny P-1, depth $60.0 \mathrm{~m} ; \mathrm{C}$ - Pompeckjoidaepollenites platoides (Pflug) Krutzsch, Yantarny P-1, depth $53.5 \mathrm{~m}$; D Extratriporopollenites clarus Pflug, 1953, Yantarny P-1 depth 53.0 m; E, F - Foraminiferal linings, Yantarny P-1, depth $59.0 \mathrm{~m}$ (E), groove No. 224, depth 14.78-15.30 m (F); G, H - Trudopollis cf. parvotrudens Pflug, 1953, Yantarny P-1, $56.0 \mathrm{~m} \mathrm{(G)}$ and $60.0 \mathrm{~m}(\mathrm{H}) ; \mathbf{I}$ - Duplopollis myrtoides Krutzsch, 1959, Yantarny P-1, depth $53.0 \mathrm{~m} ; \mathbf{J}$ Vacuopollis cf. percentus Pflug, 1953, Yantarny P-1, depth 60.0 m; K - Nudopollis simmetricus (Krutzsch) Krutzsch, Yantarny P-1, depth 60.0 m; L - numerous glauconite grains, groove No. 224, depth 18.88-18.98 m 
Palynomorphs of the Yantarny P-1 borehole

\begin{tabular}{|c|c|c|}
\hline $\begin{array}{l}\text { Depth }[\mathrm{m}] \\
\text { Age }\end{array}$ & Significant phytoplankton taxa & Significant sporomorphs \\
\hline $\begin{array}{l}9.8-10.5 \\
\text { Priabonian }\end{array}$ & $\begin{array}{l}\text { Areosphaeridium michoudii, } \\
\text { Charlesdowniea clathrata, } \\
\text { Deflandrea heterophlycta, } \\
\text { Enneadocysta pectiniformis, } \\
\text { Glaphyrocysta semitecta, } \\
\text { Cordosphaeridium funiculatum, } \\
\text { Thalassiphora fenestrata }\end{array}$ & $\begin{array}{c}\text { Castaneoideaepollis pusillus, } \\
\text { Fususpollenites fusus, } \\
\text { Intratriporopollenites insculptus, } \\
\text { Platanipollis ipelensis, } \\
\text { Quercoidites microhenrici, } \\
\text { Tricolporopollenites megaexactus, } \\
\text { Triporopollenites robustus }\end{array}$ \\
\hline $\begin{array}{l}10.8-18.3 \\
\text { Bartonian }\end{array}$ & $\begin{array}{l}\text { Heteraulacacysta porosa, } \\
\text { Rhombodinium porosum, } \\
\text { Areosphaeridium michoudii, } \\
\text { Areosphaeridium diktyoplokum, } \\
\text { Charlesdowniea clathrata, } \\
\text { Charlesdowniea coleotypha, } \\
\text { Cordosphaeridium funiculatum, } \\
\text { Enneadocysta pectiniformis, } \\
\text { Cerebrocysta bartonensis, } \\
\text { Glaphyrocysta texta } \\
\text { reworked Paleocene taxa: } \\
\text { Cerodinium speciosum }\end{array}$ & $\begin{array}{c}\text { Arecipites } \\
\text { Castaneoideaepollis pusillus, } \\
\text { Engelharedtioipollenites quietus, } \\
\text { Fususpollenites fusus, } \\
\text { Milfordia minima, } \\
\text { Myricipites rurensis } \\
\text { Platanipollis ipelensis, } \\
\text { Platycaryapollenites, } \\
\text { Quercoidites microhenrici, } \\
\text { Quercoidites henrici, } \\
\text { Sapotaceoideaepollenites, } \\
\text { Tricolporopollenites staresedloensis, } \\
\text { Tricolporopollenites megaexactus, } \\
\text { Triporopollenites robustus } \\
\text { Normapolles: } \\
\text { Nudopollis, } \\
\text { Trudopollis }\end{array}$ \\
\hline $\begin{array}{l}18.6-35.6 \\
\text { Lutetian }\end{array}$ & $\begin{array}{l}\text { Corrudinium incompositum, } \\
\text { Cordosphaeridium } \\
\text { fibrospinosum, } \\
\text { Cordosphaeridium funiculatum, } \\
\text { Phthanoperidiunium } \\
\text { crenulatum, } \\
\text { Lingulodinium } \\
\text { machaerophorum, } \\
\text { Charlesdowniea sp. } \\
\text { reworked Paleocene taxa: } \\
\text { Paleocystodinium minusculum } \\
\text { Cerodinium speciosum } \\
\text { Fibradinium annetorpense } \\
\text { Palambages morulosa }\end{array}$ & $\begin{array}{c}\text { Castaneoideaepollis pusillus, } \\
\text { Fususpollenites fusus, } \\
\text { Intratriporopollenites insculptus, } \\
\text { Quercoidites henrici, } \\
\text { Platanipollis ipelensis, Platycaryapollenites miocaenicus, } \\
\text { Tricolporopollenites fallax, } \\
\text { Tricolporopollenites liblarensis, } \\
\text { Tricolporopollenites megaexactus, } \\
\text { Tricolporopollenites staresedloensis, } \\
\text { Normapolles: } \\
\text { Pompeckjoidaepollenites subhercynicus, } \\
\text { Nudopollis, } \\
\text { Trudopollis }\end{array}$ \\
\hline $\begin{array}{l}36.3-51.0 \\
\text { Ypresian }\end{array}$ & $\begin{array}{c}\text { Cordosphaeridium funiculatum, } \\
\text { Deflandrea oebisfeldensis, } \\
\text { Eatonicysta ursulae, } \\
\text { Hystrichosphaeridium } \\
\text { tubiferum, } \\
\text { Rottnestia borusica, } \\
\\
\text { reworked Paleocene taxa: } \\
\text { Palambages morulosa } \\
\text { Cerodinium striatum } \\
\text { Spinidinium clavum } \\
\text { Isabelidinium sp. } \\
\text { Palaeocytodinium minusculum } \\
\text { Alisocysta margarita } \\
\text { reworked Cretaceous taxa: } \\
\text { Odontochitina sp. } \\
\text { Paucilobimorpha apiculata }\end{array}$ & $\begin{array}{c}\text { Castaneoideaepollis pusillus, } \\
\text { Myricipites rurensis, } \\
\text { Platanipollis ipelensis, } \\
\text { Platycaryapollenites miocaenicus, } \\
\text { Sapotaceoidaepollenites, } \\
\text { Slowakipollis, } \\
\text { Symplocoipollenites, } \\
\text { Triporopollenites robustus, } \\
\text { Tricolporopollenites staresedloensis } \\
\text { Normapolles: } \\
\text { Complexoipollenites, Extratriporopollenites clarus, } \\
\text { Nudopollis, } \\
\text { N. cf. thiergartii, } \\
\text { Oculopollis suboculus, } \\
\text { P. peneperfectus, } \\
\text { P. subhercynicus, } \\
\text { Plicatopollis plicatus, Pompeckjidaepollenites, } \\
\text { Pseodoculopollis, Stephanoporopollenites, } \\
\text { Trudopollis, } \\
\text { Trudopollis cf. articulus, } \\
\text { T. cf. bulboformis, } \\
\text { T. ordinatus, } \\
\text { Vacuopollis }\end{array}$ \\
\hline
\end{tabular}


Tabl. 1 cont.

\begin{tabular}{|c|c|c|}
\hline $\begin{array}{l}\text { Depth [m] } \\
\text { Age }\end{array}$ & Significant phytoplankton taxa & Significant sporomorphs \\
\hline $\begin{array}{l}52.0-67.0 \\
\text { Selandian }\end{array}$ & $\begin{array}{c}\text { Alterbidinium circulum, } \\
\text { Damassadinium californicum, } \\
\text { Cerodinium diebelii, } \\
\text { Cerodinium speciosum, } \\
\text { Cerodinium striatum, } \\
\text { Spinidinium densispinatum, } \\
\text { Spinidinium clavum, } \\
\text { S. echinoideum } \\
\text { Fibradinium annetorpense, } \\
\text { Alisocysta margarita, } \\
\text { Isabelidinium viborgense, } \\
\text { Cladopyxidium sp., } \\
\text { Paralacaniella sp., } \\
\text { Palaeocystodinium minusculum } \\
\text { Palaeotetradinium silicorum, } \\
\text { Caligodinium aceras, } \\
\text { Fibrocysta ovalis, } \\
\text { Palambages morulosa, } \\
\text { Phanerodinium sp. } \\
\\
\text { reworked Cretaceous taxa: } \\
\text { Isabelidinium cooksoniae } \\
\text { Isabelidinium bujakii } \\
\text { Chattangiella tripartita } \\
\text { Senoniasphaera rotundata } \\
\text { Laciniadinium } \\
\text { Odontochitina }\end{array}$ & $\begin{array}{c}\text { Castaneoideaepollis pusillus, } \\
\text { Gothanipollis, } \\
\text { Myricipites rurensis, } \\
\text { Pentapollis, } \\
\text { Platanipollis ipelensis, } \\
\text { Platycaryapollenites levis, } \\
\text { Quercoidites henrici, } \\
\text { Symplocoipollenites annulus/rotundus, } \\
\text { Tricolporopollenites dolium, Tricolporopollenites } \\
\text { mansfeldensis, } \\
\text { Normapolles: } \\
\text { Duplopollis myrtoides, Interporopollenites, } \\
\text { Nudopollis terminalis, } \\
\text { Oculopollis, } \\
\text { O. baculotrudens, } \\
\text { Pompecjoidaepollenites platoides, } \\
\text { Pseudoculopollis, } \\
\text { Thomsonipollis, } \\
\text { Trudopollis, } \\
\text { T. classotrudens, } \\
\text { T. cf. parvotrudens, } \\
\text { T. plenus, } \\
\text { Vacuopollis cf. parcentus }\end{array}$ \\
\hline
\end{tabular}

Palynomorphs of groove No. 224 of the Primorskiy mine

\begin{tabular}{|l|c|c|}
\hline \multicolumn{1}{|c|}{$\begin{array}{c}\text { Depth }[\mathrm{m}] \\
\text { Age }\end{array}$} & Significant phytoplankton taxa & Significant sporomorphs \\
\hline & Areosphaeridium diktyoplokum, & \\
& Areosphaeridium michoudii, & \\
& Charlesdowniea clathrata, & Chytreisphaeridia parva, \\
& Cordosphaeridium funiculatum, & \\
Deflandrea heterophlycta, & Castaneoideaepollis pusillus, \\
$14.17-18.98$ & Engelhardtioipollenites punctatus, \\
Bartonian & Fususpollenites fusus, \\
and & Glaphyrocysta semitecta, \\
Priabonian & Glaphyrocysta texta, & Fuercoidites microhenrici, Sapotaceoideaepollenites, \\
& Hetraulacacysta porosa, & Tricolporopollenites staresedloensis, \\
& Homotryblium pallium, & \\
& Microdinium reticulatum, & \\
& Rhombodinium porosum & \\
&
\end{tabular}

holes: Kharkovskoye, Krasnovka, Rodniki), in Lithuania (Kalvarija borehole - Grigelis, 1996; Kasiński and Piwocki, 2004), in the vicinity of Tuchola (Słodkowska, 2004), and in the northeastern part of the Polish Lowlands, in the Klucznik and Wysoka Wieś boreholes in northern Poland (Słodkowska, 2009; Słodkowska and Gałązka, 2015). The mid Paleocene age of the Lubava Fm. allows correlation with the upper part of the Puławy Formation in the Polish Lowlands.

The Sambian Formation (Yantarny P-1 borehole, 35.9-51.7 $\mathrm{m}$ depth) revealed a dinoflagellate cyst assemblage corresponding to Ypresian (Early Eocene) D7 Zone interval (Köthe, 2012) and a pollen assemblage with a large content of palaeotropical elements. This implies an important stratigraphic hiatus between the Lubava and Sambian formations, corresponding to the Thanetian-earliest Ypresian.
Sediments corresponding to the D7 dinoflagellate cyst Zone are not known in adjacent northeastern Poland, though this dinocyst zone D8 is recognized in NE Poland (Słodkowska and Gałązka, 2015).

The Alka Formation (Yantarny P-1 borehole, 18.5-35.9 m depth) consists of three lithostratigraphic units: the (1) Lower Wild Earth, (2) Lower Blue Earth, and (3) Lower Quicksand members and contains a phytoplankton assemblage corresponding to the D9 Zone (Köthe, 2012), probably indicating a Lutetian age. The pollen assemblage here is still characterized by a large content of palaeotropical elements. Thus, a significant stratigraphic hiatus is recognized between the Sambian and Alka formations and corresponds to the mid Ypresian-lower Lutetian. According to our results, the Alka Formation can be correlated with the lower part of the Pomeranian Formation 
in NE Poland, close to the Kaliningrad region (Piwocki, 2004). Deposits of the lower Pomeranian Formation are lithologically similar to the Lower Quicksand Member: they comprise fine-grained, grey-greenish glauconite-quartz sand in the bottom part of the formation with an admixture of fine quartz gravel and siderite concretions.

Redeposition was not limited to the Lubava Formation, but took place also during the accumulation of the Sambian and Alka formations, indicated by the presence of Paleocene taxa within the phytoplankton assemblages. A distinct admixture of biotite is also observed in the Sambian Formation, resulting from the erosion of clastic material from the Lubava Formation, where biotite is very common.

The Prussian Formation (Yantarny P-1 borehole, 9.3-18.5 m depth) yielded a dinoflagellate cyst assemblage (Table 3) corresponding to the D11-D12 zones interval (Köthe, 2012) dated to the Bartonian-Priabonian. Based on these data, this formation is correlated with the upper Pomeranian Formation in Poland. A similar palynomorph assemblage was recorded in an equivalent interval from the northeastern part of the Polish Lowlands (Słodkowska, 2009; Słodkowska and Gałązka, 2015). The uppermost units of the Prussian Formation - the Upper Quicksand and White Wall - were not recognized in the studied sections, but are known from the nearby Primorskiy opencast amber mine (Grabowska and Kohlman-Adamska in Kosmowska-Ceranowicz et al., 1997). Similar deposits occur also along the western margins of the Gulf of Gdańsk (Fig. 13): they were distinguished in the Chłapowo I, Chłapowo II and Chłapowo III boreholes (Piwocki et al., 1985; Grabowska, 1987) and are composed of quartz sand and silt with glauconite and amber and have a similar palynological spectrum. These deposits were also recognized in the Chałupy-92 and Kuźnica-92 boreholes on the Hel Peninsula (Kramarska, 2006, 2010) and are attributed to the uppermost Pomeranian Formation, which is the exact stratigraphical equivalent of the amber-bearing deposits of the Prussian Formation. However, the amber-bearing Paleogene strata along the western margin of the Gulf of Gdańsk are at a depth interval of 50-70 m b.s.l., i.e. $>50 \mathrm{~m}$ deeper than on the Sambian Peninsula. This might be the result of post-sedimentary tectonic activity (Kaplan and Krasnov, 1977; Kramarska, 2006).

Our multidisciplinary results allow reconstruction of several changes in the sedimentation regime; in particular, we can examine fluctuations in the content of individual components, notably lithological features and organic matter composition of the sedimentary basin during the Paleocene-Eocene and, hence, reconstruct its palaeogeography (Table 4 ).

The Paleocene-Eocene (Lubava-Prussian formations) in the studied region is incomplete and contains numerous gaps, resulting in sedimentary discontinuities.

The first stratigraphic gap, corresponding to the Lower Palaeocene (Danian), is recognized between the mid Paleocene Lubava Fm. and the Cretaceous rocks.

Several gaps within the Lubava and Sambian formations are emphasised by horizons of silica cementation. Preserved fragments with a coarse-grained texture indicate that the matrix probably originated from the erosion and redeposition of clays (or claystones) within the same sedimentary basin. A few hardground surfaces were observed on the top of some cementation horizons. The most distinct hardground horizon is recognized at the boundary between the Lubava and Sambian formations, where an important stratigraphic gap corresponding to the Thanetian-lowermost Ypresian, is recognized (Fig. 14).

The Paleogene deposits accumulated in the marine basin during a single first-order transgressive-regressive cycle in a shallow shelf environment. Thus, deposits of the Lubava For- mation originated in the inner neritic zone (Table 4). After an important gap corresponding to the Thanetian-earliest Ypresian, shallow-marine sedimentation was restored during the Ypresian. An erosional surface marked with a basal conglomerate composed of a phosphate horizon at the base of the succession is related to the next transgression. At a depth of $36.7 \mathrm{~m}$ there occurs the next erosional surface. Above that, six simple sedimentary cycles (fining-upward sequences) are visible, with a layer of quartz gravel at the base of each cycle; moreover, the sediments are highly bioturbated. The sediments of the Sambian and Alka formations represent middle neritic sediments (Fig. 14).

The variable heavy minerals composition indicates a change in the source area, depending on the location of the basin shoreline. In the lower part of the section, the detrital material composed of resistant minerals was probably supplied to the Paleocene basin both from the destruction of older sedimentary rocks (Jurassic and Devonian) surrounding the basin to the north and north-east, as well as directly from crystalline rocks. In northern Poland, Jurassic deposits are dominated by resistant minerals associated with amphiboles (hornblende) and biotite, less often pyroxene (Radlicz, 1972). Garnet, zircon and tourmaline predominate among heavy minerals in the Devonian strata there (Järvellil et al., 2015). In the higher part of the profile, a dominance of the epidote is observed, indicating the progressive migration to the north of the Eocene basin shoreline and addition of detrital material mostly from the crystalline rocks of the Baltic Shield.

Numerous cemented horizons (Fig. 14) occurred as a result of increased silica precipitation during upwelling processes (cf. Blazhchishin, 1999). The preserved elements of the coarse-grained structure indicate that the cement material probably originated during dilution and redeposition of clay (or claystones) in the same sedimentary basin. Only rare pollen grains reached this area from the distant land. Redeposition of Cretaceous and Paleocene palynomorphs is recorded in the Lower Eocene strata. Deposits from the upper part of the Lower Eocene (dinoflagellate cyst Zone D8) were not found at the base of the next sedimentary package, corresponding to the dinoflagellate cyst Zone D9 (mid-Lutetian). There is a distinct erosional surface marked by a concentration of coarse quartz grains. This probably corresponds to the next stratigraphic gap, encompassing the uppermost Lutetian (dinoflagellate cyst Zone D10). The uppermost part of the mid-Eocene is represented by shallow-water marine deposits of the next transgressive-regressive cycle. The "Upper Wild Earth" and the Upper Blue Earth members accumulated during several sedimentary cycles: medium and coarse sand fractions dominate in the lower part of the each cycle, and silty clay deposits build their upper parts. A sedimentary succession representing regressive facies occurs in the uppermost part of the section (dinoflagellate cyst zones D11-D12, Bartonian-Priabonian). Levels rich in amber grains are related to these facies. Deposits of the Prussian Formation formed in the inner neritic zone: the lower part in intertidal conditions, the middle part insubtidal conditions and the upper part again in intertidal conditions (Table 4).

The predomination of garnets over epidotes in the Lubava Formation is not high enough to define it as dominant, which, according to Katinas (1971), is a characteristic feature of Paleocene deposits in the Sambian Peninsula. This difference occurred probably due to analysis of the mineral composition of different fractions. The $0.125-0.063 \mathrm{~mm}$ fraction was analysed herein, whereas the results of Katinas (1971) referred to the $0.25-0.1 \mathrm{~mm}$ fraction, in which the relation of epidote to garnets favours the latter heavy mineral. 
Lithostratigraphic correlation of the Sambian Peninsula and NE Poland

\begin{tabular}{|c|c|c|c|}
\hline \multirow{2}{*}{$\begin{array}{l}\text { Dinoflagellata } \\
\text { zones }\end{array}$} & Sambian Peninsula (nearby Yantarny P-1 borehole) & \multicolumn{2}{|c|}{ NE Poland } \\
\hline & Formation & Member & Formation \\
\hline D 13 & Palve & Green Wall & Lower Mosina \\
\hline \multirow{3}{*}{ D 12} & \multirow{4}{*}{ Prussian } & White Wall & \multirow{4}{*}{ Pomerania (upper part) } \\
\hline & & Upper Quicksand & \\
\hline & & Upper Blue Earth & \\
\hline D 11 & & Upper Wild Earth & \\
\hline \multicolumn{4}{|l|}{ D 10} \\
\hline \multirow{3}{*}{ D 9} & \multirow{3}{*}{ Alka } & Lower Quicksand & \multirow{4}{*}{ Pomerania (lower part) } \\
\hline & & Lower Blue Earth & \\
\hline & & Lower Wild Earth & \\
\hline D 8 & & & \\
\hline D 7 & \multicolumn{2}{|l|}{ Sambian } & \\
\hline \multicolumn{4}{|l|}{ D 6} \\
\hline \multicolumn{4}{|l|}{ D 5} \\
\hline D 4 & \multirow{2}{*}{\multicolumn{2}{|c|}{ Lubava }} & Odra \\
\hline D 3 & & & \multirow{3}{*}{ Puławy } \\
\hline D 2 & & & \\
\hline D 1 & & & \\
\hline
\end{tabular}

grey - stratigraphic gap

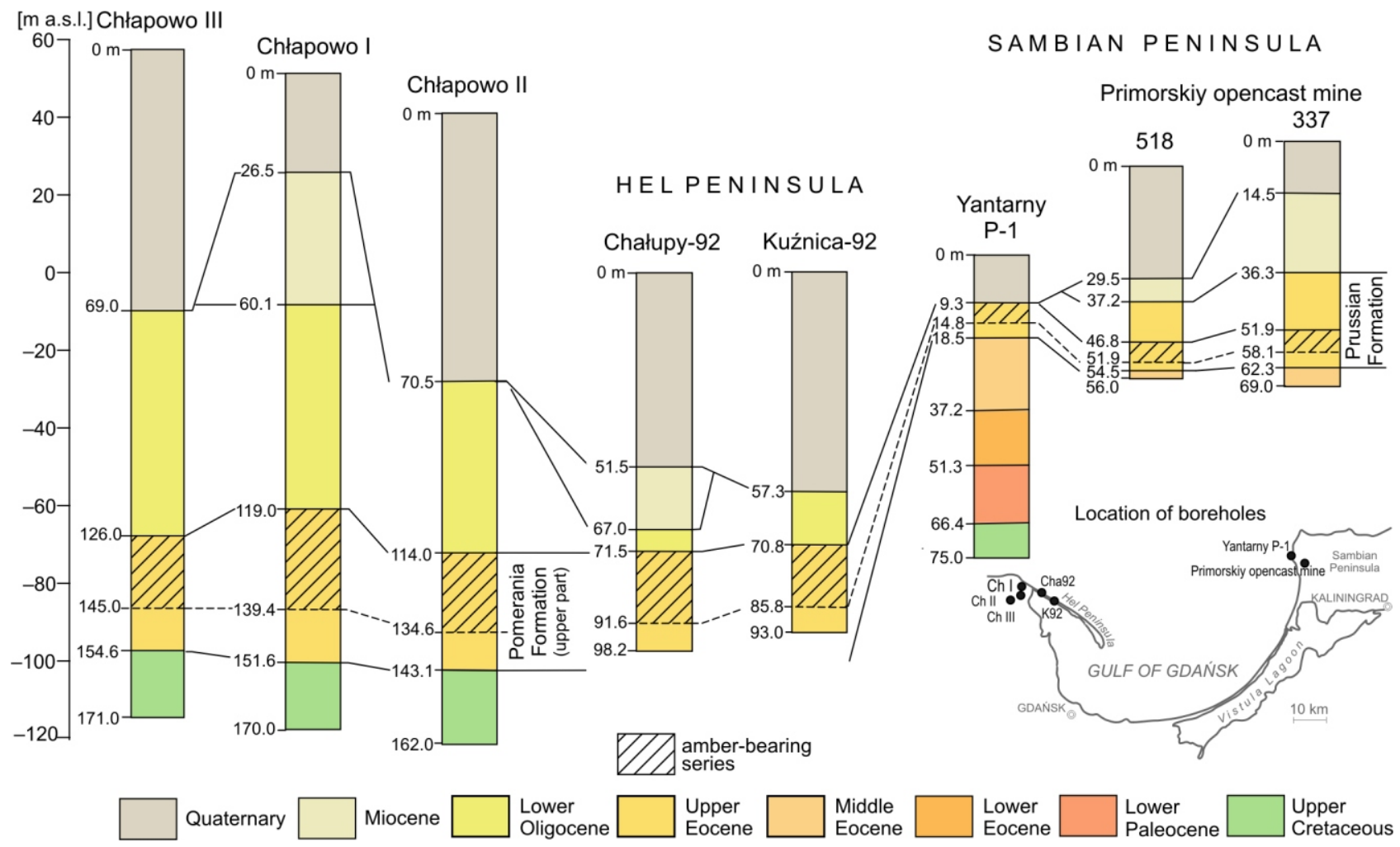

Fig. 13. Lithostratigraphic correlation of the Paleogene deposits in the Gulf of Gdańsk area 
Depositional environments in Paleogene based on lithological and palynological data

\begin{tabular}{|c|c|c|c|c|}
\hline Age/lithostratigraphy & Lithological features & Mineral composition & Palynological matter & $\begin{array}{c}\text { Sedimentary environ- } \\
\text { ment }\end{array}$ \\
\hline $\begin{array}{l}\text { Upper Eocene } \\
\text { Priabonian } \\
\text { D12 } \\
\text { Prussian Formation }\end{array}$ & $\begin{array}{c}\text { Heterolithe of sand and } \\
\text { silty sand with dis- } \\
\text { persed coarse quartz } \\
\text { grains }\end{array}$ & $\begin{array}{l}\text { epidote assemblage; } \\
\text { significant chlorite ad- } \\
\text { mixture }\end{array}$ & $\begin{array}{c}\text { Sporomorphs - single; } \\
\text { Normapolles group - single; } \\
\text { Phytoplankton - frequent; } \\
\text { Dinocysts - common, gonyaulacoid } \\
\text { dinocyst morphotype predominated; } \\
\text { Acritarchs - sporadically; } \\
\text { Others: foraminiferal linings - single; } \\
\text { glauconite aggregates - single }\end{array}$ & $\begin{array}{c}\text { inner neritic, intertidal } \\
\text { zone, not too far from } \\
\text { a shoreline }\end{array}$ \\
\hline \multirow{2}{*}{$\begin{array}{l}\text { Middle Eocene } \\
\text { Bartonian } \\
\text { D11 } \\
\text { Prussian Formation }\end{array}$} & $\begin{array}{l}\text { silty sand, silt and clay } \\
\text { with amber; laminae of } \\
\text { dark clay and } \\
\text { phytodetritus }\end{array}$ & \multirow{2}{*}{$\begin{array}{l}\text { transparent minerals } \\
\text { predominantly of the } \\
\text { epidote assemblage; } \\
\text { significant glauconite } \\
\text { content }\end{array}$} & \multirow{2}{*}{$\begin{array}{c}\text { Sporomorphs - rare; } \\
\text { Normapolles group - single; } \\
\text { Phytoplankton - common; } \\
\text { Dinocysts - abundant, gonyaulacoid } \\
\text { dinocyst morphotype predominant; } \\
\text { Acritarchs - frequent; } \\
\text { Others: } \\
\text { foraminiferal linings - single; } \\
\text { glauconite aggregates - frequent }\end{array}$} & $\begin{array}{l}\text { inner neritic, subtidal } \\
\text { zone more distant } \\
\text { from a shoreline }\end{array}$ \\
\hline & $\begin{array}{l}\text { Heterolithe of silty sand } \\
\text { and silt; } \\
\text { at the bottom, an ero- } \\
\text { sional surface }\end{array}$ & & & $\begin{array}{c}\text { inner neritic, } \\
\text { intertidal zone, not } \\
\text { too far from a shore- } \\
\text { line }\end{array}$ \\
\hline \multirow{3}{*}{$\begin{array}{l}\text { Middle Eocene } \\
\text { ? Lutetian } \\
\text { ? D9 } \\
\text { Alka Formation }\end{array}$} & $\begin{array}{l}\text { vari-grained sand, } \\
\text { bioturbated }\end{array}$ & \multirow{2}{*}{$\begin{array}{l}\text { epidote assemblage } \\
\text { with disthene and zir- } \\
\text { con; frequent siderite; } \\
\text { substantial calcium } \\
\text { carbonate content }\end{array}$} & \multirow{3}{*}{$\begin{array}{c}\text { Sporomorphs - rare; } \\
\text { Normapolles group - frequent; } \\
\text { Phytoplankton - common; Dinocysts } \\
\text { - abundant, gonyaulacoid dinocyst } \\
\text { morphotype predominant; } \\
\text { Acritarchs - sporadic; } \\
\text { Others: } \\
\text { foraminiferal linings - single; } \\
\text { glauconite aggregates - single }\end{array}$} & \multirow{6}{*}{$\begin{array}{c}\text { middle neritic, } \\
\text { periodically } \\
\text { shallowing }\end{array}$} \\
\hline & fine-grained sand & & & \\
\hline & $\begin{array}{l}\text { Heterolithe hic deposits } \\
\text { of medium and coarse } \\
\text { grained sand; erosional } \\
\text { surface at the top }\end{array}$ & \multirow{4}{*}{$\begin{array}{l}\text { epidote assemblage } \\
\text { with frequent occur- } \\
\text { rence of zircon at the } \\
\text { bottom; small } \\
\text { glauconite content in- } \\
\text { creases towards the } \\
\text { top }\end{array}$} & & \\
\hline \multirow{3}{*}{$\begin{array}{l}\text { Lower Eocene } \\
\text { Middle Ypresian } \\
\text { D7 } \\
\text { Sambian Formation }\end{array}$} & $\begin{array}{l}\text { silty sand, laminated } \\
\text { and bioturbated; } \\
\text { lithified intervals of } \\
\text { quartz wacke are pres- } \\
\text { ent; clear erosional sur- } \\
\text { face at the top }\end{array}$ & & \multirow{3}{*}{$\begin{array}{c}\text { Sporomorphs - rare; } \\
\text { Normapolles group - frequent; } \\
\text { Phytoplankton - common; } \\
\text { Dinocysts - abundant, gonyaulacoid } \\
\text { dinocyst morphotype predominant; } \\
\text { Acritarchs - sporadic; } \\
\text { Others: foraminiferal linings - fre- } \\
\text { quent }\end{array}$} & \\
\hline & $\begin{array}{l}\text { silt and silty clay, lami- } \\
\text { nated and bioturbated }\end{array}$ & & & \\
\hline & $\begin{array}{l}\text { silty sand, laminated } \\
\text { and bioturbated; } \\
\text { lithified intervals of } \\
\text { quartz wacke are pres- } \\
\text { ent; thin phosphatic } \\
\text { layer and an erosional } \\
\text { surface at the bottom }\end{array}$ & & & \\
\hline \multirow{3}{*}{$\begin{array}{l}\text { Middle Paleocene } \\
\text { Selandian } \\
\text { D3-D4 } \\
\text { Lubava Formation }\end{array}$} & $\begin{array}{c}\text { silified siltstone with } \\
\text { phosphates and phos- } \\
\text { phatic sand; } \\
\text { two hardgrounds inside } \\
\text { the lowermost interval }\end{array}$ & \multirow{3}{*}{$\begin{array}{c}\text { predomination resis- } \\
\text { tant minerals and am- } \\
\text { phibole; frequent } \\
\text { chlorite and glauconite }\end{array}$} & \multirow{3}{*}{$\begin{array}{c}\text { Sporomorphs - rare; } \\
\text { Normapolles group - single; } \\
\text { Phytoplankton - common; } \\
\text { Dinocysts - abundant, equal quantity } \\
\text { of mainly gonyaulacoid and } \\
\text { peridinioid morphotypes; } \\
\text { Acritarchs - rare; } \\
\text { Others: } \\
\text { foraminiferal linings - rare }\end{array}$} & \multirow{3}{*}{$\begin{array}{l}\text { inner neritic, gradu- } \\
\text { ally shallowing to- } \\
\text { wards the top }\end{array}$} \\
\hline & $\begin{array}{l}\text { decalcified siltstone; } \\
\text { a hardground at the } \\
\text { bottom }\end{array}$ & & & \\
\hline & $\begin{array}{l}\text { siltstone and silt, partly } \\
\text { bioturbated; rare hori- } \\
\text { zons of silification }\end{array}$ & & & \\
\hline
\end{tabular}




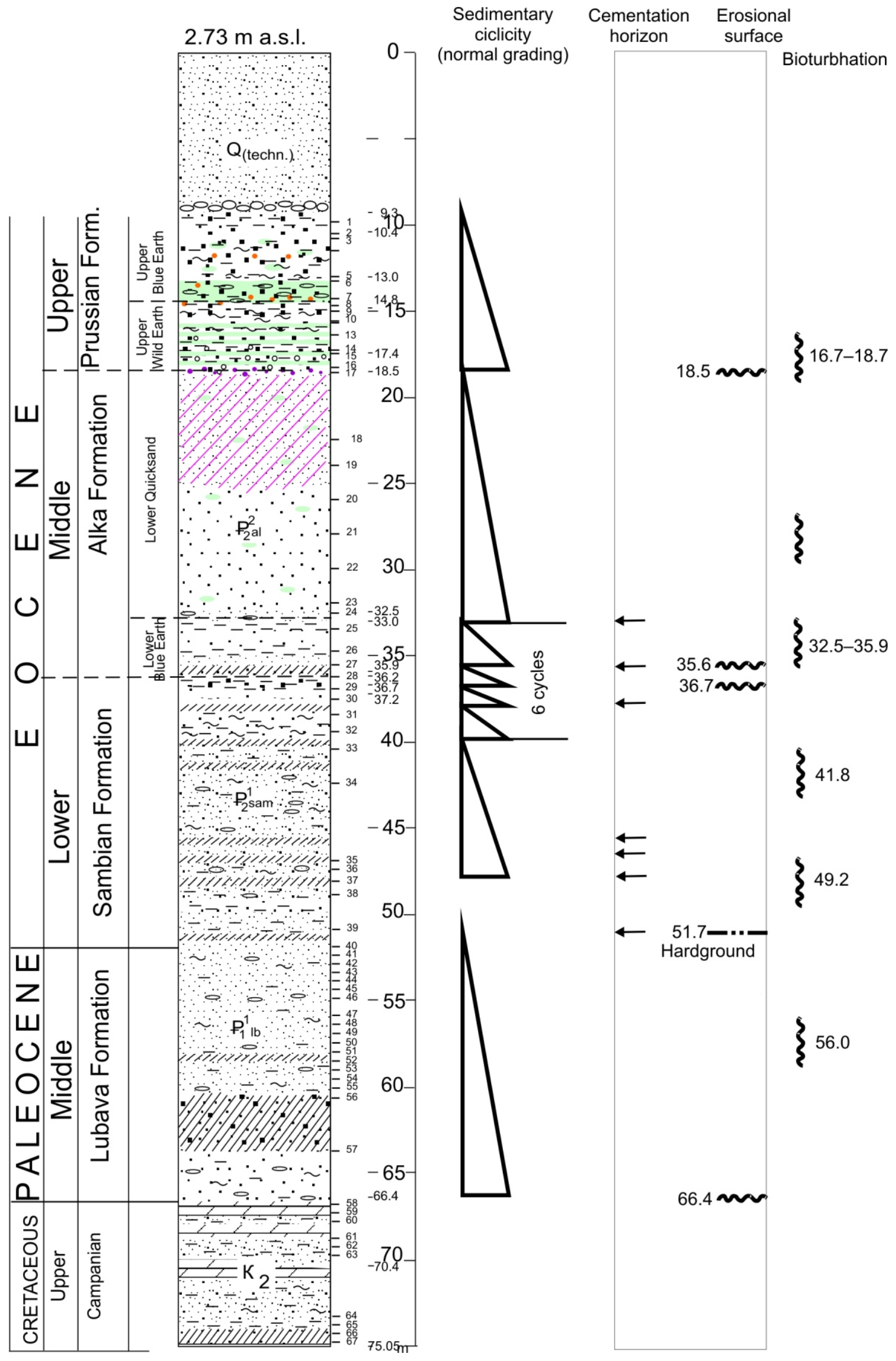

Fig. 14. Sedimentological Log of the Yantarnyj P-1 borehole 


\section{CONCLUSIONS}

The lowermost Paleogene deposits, overlying Upper Cretaceous marls, are represented by siliclastic strata of Selandian age, suggesting an important stratigraphic hiatus corresponding to the Lower Paleocene.

Successions of the Lubava and Sambian formations contain numerous horizons of silica cementation, which result from upwelling events. Fragments with a coarse-grained texture indicate that the matrix was probably derived from the erosion and redeposition of clays (or claystones) within the same sedimentary basin. Several hardground surfaces were observed at the top of certain cementation horizons. The hardground horizon at the boundary between the Lubava and Sambian formations is linked with a stratigraphic gap corresponding to the Upper Paleocene-lowermost Eocene. This stratigraphic gap is recognized between the Sambian and Alka formations (upper Ypresian-lower Lutetian).

Another stratigraphic gap corresponding to the upper Lutetian, but without a cementation horizon, is recorded between the Alka and Prussian formations. The lithology of the overlying Prussian Formation indicates a substantial change in the sedimentation regime. The grain size composition and the glauconite content is different; several phosphate horizons and fine quartz gravels occur in the lower part of the succession. The palynomorph content and their taxonomic diversity are also higher. Amber locally accumulated in significant amounts, becoming one of the most important lithological elements.

The Lubava, Sambian and Alka formations, characterized by palynological assemblages dominated by marine phytoplankton taxa, seem to have accumulated at a considerable distance from the shoreline. Fluctuations in the ratio of peridinioidean and gonyaulacoidean dinoflagellate cysts (see Table 4) suggest minor sea level oscillations.
A large dominance of epidote over other minerals was commonly registered in all sections of the Prussian Formation studied (Katinas, 1971; Kosmowska-Ceranowicz and Müller, 1985; Kosmowska-Ceranowicz et al., 1997), as well as in the deposits of the correlative upper part of the Pomeranian Formation in the Gdańsk and Olsztyn regions in Poland. All these areas belong to the same Eastern Mineralogical Province (KosmowskaCeranowicz, 1987), where an epidote mineralogical assemblage passing into an epidote assemblage with an upwards increase in amber is typical of the Upper Eocene.

Acknowledgements. The work was carried out as part of the research project no. 6.22.1202.00.0 granted by the statutory funds of the Polish Geological Institute - National Research Institute. The basis for carrying out the research was a cooperation agreement between the Polish Geological Institute - National Research Institute (PGI-NRI) and the Atlantic Branch of the P.P. Shirshov Institute of Oceanology, Russian Academy of Science (IO RAS). The authors would like to thank all those who cooperated in the task. It was possible due to the excellent cooperation and commitment of colleagues from the Atlantic Branch IO RAS in Kaliningrad with the special input of Georgy Malafieyev, who cooperated in measuring and sampling the borehole cores. Special thanks are due to the team of palaeontologists from the Carpathian Branch of the PGI-NRI, in which the leader Prof. B. Olszewska was responsible for the foraminifer and nannoplankton analyses, and to Dr. N. Lukashina and Ms. O. Dmitrienko from the Atlantic Branch, IO RAS, for detailed foraminifer and nannoplankton analysis of the Cretaceous deposits. We thank Prof. A. Maliszewska for her petrographic expertise regarding the sandstone samples. We are grateful to all collaborators from the Marine Geology Branch of PGI-NRI for their preliminary laboratory work. The authors warmly thank the reviewers, and especially Dr. lakovleva who did much work improving our paper.

\section{REFERENCES}

Aleksandrova, G.N., Zaporozhets, N.I., 2008a. Palynological characteristics of Upper Cretaceous and Paleogene deposits on the West of the Sambian Penninsula (Kaliningrad Region), Part 1. Stratigraphy and Geological Correlation, 16: 295-316.

Aleksandrova, G.N., Zaporozhets, N.I., 2008b. Palynological characteristics of Upper Cretaceous and Paleogene deposits on the West of the Sambian Penninsula (Kaliningrad Region), Part 2. Stratigraphy and Geological Correlation, 16: 528-539.

Blazhchishin, A.l., 1974. Geologicheskoye stroenie podvodnogo beregovogo sklona Sambijskogo poluostrova. Regionalnaya geologiya Pribaltiki: 161-168. Zinatne, Riga

Blazhchishin, A.l., 1999. Eocene paleogeography and sedimentation in the Baltic deep and adjoining areas. In: Investigations into Amber (eds. B. Kosmowska-Ceranowicz and H. Paner): 19-26. Muzeum Archeologiczne w Gdańsku.

Eisenack, A., 1938. Die Phosphoritknollen der Bernsteinformation als überlieferer tertiären Planktons. Schriften der PhysikalischÖkonomischen Gesellschaft zu Königsberg, 70: 181-188.

Eisenack, A., 1954. Mikrofossilien aus Phosphoriten des samländischen Unter-Oligozäns und über die Einheitlichkeit der Hystrichosphaerideen. Palaeontographica, A, 105: 49-95.

Grabowska, I., 1987. Palynofloristic and microplanktonic characteristic of the Tertiary sediments in Northern Poland based on the sections of the boreholes Chłapowo I and Chłapowo III (in Polish with English summary). Biuletyn Instytutu Geologicznego, 356: $65-87$.

Grigelis, A.A., 1996. Lithostratigraphic subdivision of the Cretaceous and Palaeogene of Lithuania. Geologija, 20: 45-55.

Grigelis, A.A., Baltakis, V., Katinas, V., 1971. Stratigrafiya paleogenovykh otlozhenij Pribaltiki (in Russian). Izwiestiya Akademii Nauk SSSR, Ser. Geol., 3: 107-116.

Grigelis, A.A., Burlak, A.F., Zosimovich, V.Y., Ivanik, M.M., Kraeva, E.A., Luleva, S.A., Stotland, A.B., 1988. Novye dannye po stratigrafii i paleogeografii paleogenovyh otlozheniy zapada evropeyskoy chasti SSSR. Sovetskaya geologiya, 12: 41-54.

Jaworowski, K., 1987. Origin of amber-bearing Palaeogene sediments in the area of Chłapowo (in Polish with English summary). Biuletyn Instytutu Geologicznego, 356: 89-101.

Järvelill, J.-I., Kleesment, A., Raukas, A., 2015. Accumulation of heavy minerals in the eastern coast of the Gulf of Riga, south-western Estonia. Bulletin of the Geological Society of Finland, 87: 67-78.

Jentzsch, A., 1876. Beiträge zur Kenntnis der Bernsteinformation. Schrift. Königl. Phys.- Ökonom. Ges. Königsberg, 17: 101-108. 
Kaplan, A.A., Grigelis, A.A., Strelnikova, N.I., Glikman, L.S., 1977. Stratigrafiya i korrelaciya paleogenovyh otlozheniy yugo-zapada Pribaltiki (in Russian). Sovetskaya geologiya, 4: 30-43.

Kaplan, A.A., Krasnov, S.G., 1977. Analiz tektonicheskogo stroeniya i razvitiya territorii Kaliningradskoy oblasti v paleogene (in Russian). In: Geologicheskiye pozicil severo-zapadnoi okrainy Russkoi plity $v$ svete novykh geologo-strukturnykh dannykh. Min. geologii RSFSR, Geologicheskiy fond RSFSR, Moskva: 50-71.

Kasiński, J.R., Piwocki, M., 2004. Bernstein-Vorkommen in Paläogene Lagerstätten Polens. Exkursionführer und Veröffentlichungen Gesellchaft für Geowissenschaften, 224: 63-64.

Kasiński, J.R., Kramarska R., 2008. Sedimentary environment of amber-bearing association along the Polish-Russian Baltic coastline. Exkursionführer und Veröffentlichungen Gesellchaft für Geowissenschaften, 236: 46-57.

Kasiński, J.R., Słodkowska, B., 2014. Bursztynonośne osady eocenu wschodniego obrzeżenia epikontynentalnego basenu Morza Północnego (in Polish). LXXXIII Zjazd Naukowy Polskiego Towarzystwa Geologicznego „Wyzwania geologii regionu lubelskiego", Biała Podlaska, 29-31.05.2014, abstrakt: 23.

Kasiński, J.R., Tołkanowicz, E., 1999. Amber in the northern Lublin Region - origin and occurrence. In: Investigations into Amber (eds. B. Kosmowska-Ceranowicz and H. Paner): 41-51. Muzeum Archeologiczne w Gdańsku, Gdańsk.

Katinas, V., 1971. Amber and amber-bearing deposit of the southern Baltic area (in Russian with English summary). Mintis, Vilnius.

Kaunhowen, F., 1914. Bernstein. Die Nutzbaren Mineralien, 2 : 440-535. Verlag Dammer \&Tietze, Stuttgart.

Kharin, G.S., Lukashina, N.P., 2002. Accumulation conditions and correlation of the Upper Eocene amber-bearing Prussian Formation, Kaliningrad Region. Stratigraphy and Geological Correlation, 10: 189-195.

Knox, R., Bosch, A., Rasmussen, E.S., Heilmann-Clausen, C., Hiss M., de Lugt, I., Kasiński, J.R., King, C., Köthe, A., Słodkowska, B., Standke, G., Vanderberghe, N., 2010. Cenozoic. In: Petroleum Geological Atlas of the Southern Permian Basin Area (eds. H. Doornenbal and A. Stevenson): 212-223 European Association of Geoscientists and Engineers Publications b.v., Houten.

Kosmowska-Ceranowicz, B., 1987. Mineralogical-petrographic characteristics of the Eocene amber-bearing sediments in the area of Chłapowo, and the Palaeogene sediments of northern Poland (in Polish with English summary). Biuletyn Instytutu Geologicznego, 356: 29-50.

Kosmowska-Ceranowicz, B., Müller, C., 1985. Lithology and calcareous nannoplankton in amber-bearing Tertiary sediments from borehole Chłapowo (Northern Poland). Bulletin of the Polish Academy of Sciences, Earth Sciences, 33: 119-129.

Kosmowska-Ceranowicz, B., Kohlman-Adamska, A., Grabowska, I., 1997. Erste Ergebnisse zur Lithologie und Palynologie der bernsteinfuhrenden Sedimente im Tagebau Primorskoje. Metalla, 66: 5-17.

Köthe, A., 2012. A revised Cenozoic dinoflagellate cyst and calcareous nannoplankton zonation for the German sector of the southeastern North Sea Basin. Newsletters on Stratigraphy, $\mathbf{4 5}$ 189-220.

Kramarska, R., 2006. Paleogen i neogen południowego Bałtyku i jego wybrzeża (in Polish). Ph.D. thesis, Państwowy Instytut Geologiczny - Państwowy Instytut Badawczy, Gdańsk.

Kramarska, R., 2010. Paleogen południowego Bałtyku i wybrzeża ze szczególnym uwzględnieniem osadów bursztynonośnych (in POlish). In: Bursztyn, poglaady, opinie. Tom 2. Materiały z seminariów Amberif 2005-2009 (eds. B. Kosmowska-Ceranowicz and W. Gierłowski): 17-25.

Kramarska, R., Kasiński, J.R., Piwocki, M., Słodkowska, B., Lukashina, N.P., Sivkov, V., 2004. Korelacja utworów paleogenu i neogenu północnej Polski i Okręgu Kaliningradzkiego (Rosja) ze szczególnym uwzględnieniem osadów bursztynonośnych (in Polish). Archiwum Państwowego Instytutu Geologicznego - Oddział Geologii Morza, Gdańsk.

Kramarska, R., Kasiński, J.R., Sivkov, V., 2008. Paleogene amber in situ in Poland and neighbouring countries - geology, mining and perspectives (in Polish with English abstract). Górnictwo Odkrywkowe, 50: 97-110.

Krasnov, S.G., Kaplan, A.A., 1976. O genezise yantarenosnyh otlozheniu paleogena Kaliningradskoy oblasti po dannym litologicheskikh issledovaniy (in Russian). Litologiya i poleznye iskopaemye, 4: 95-106.

Lukashina, N.P., 2010. The Southern Baltic Seas in the Paleogene according to the Study of the Foraminifera. Oceanology, 50: 386-396.

Moore, P.D., Webb, J.A., Collinson, M.E., 1991. Pollen Analysis. Blackwell, Oxford.

Noetling, F., 1888. Die Fauna des samländischen Tertiärs. Abhandlungen zur Geologischen Specialkarte von Preussen und den Thüringischen Staaten 1888 Bd. 6, H. 4 Verlag der Neumann'schen Kartenhandlung, Berlin.

Powell, A.J. 1992. Dinoflagellate cysts of the Tertiary System. British Micropalaeontological Society Publication Series: 155-251. Chapman \& Hall, London.

Paškevičius, J., 1997. Paleogene. In: The Geology of the Baltic Republics (ed. J. Paškevičius): 271-293. Vilnius University, Vilnius.

Piwocki, M., 2004. Paleogen (in Polish). In: Budowa geologiczna Polski, T. I, Stratygrafia, cz. 3a, Kenozoik, Paleogen, Neogen (eds. M. T. Peryt and M. Piwocki): 22-71. Państwowy Instytut Geologiczny, Warszawa.

Piwocki, M, Olkowicz-Paprocka, I., Kosmowska-Ceranowicz, B., Grabowska, I., Odrzywolska-Bieńkowa, E., 1985 Stratygrafia trzeciorzędowych osadów bursztynonośnych okolic Chłapowa koło Pucka (in Polish). Prace Muzeum Ziemi, 37: 61-77.

Radlicz, K., 1972. Lithology of the Upper Jurassic deposits in north-eastern Poland (in Polish with English summary). Biuletyn Instytutu Geologicznego, 261: 55-169.

Ritzkowski, S. 1997. K-Ar Altersbestimmungen der bernsteinführenden Sedimente des Samlandes (Paläogen, Bezirk Kaliningrad). Metalla, 66: 19-24.

Słodkowska, B., 2004. Palynological studies of the Paleogene and Neogene deposits from the Pomeranian Lakeland area (NW Poland). Polish Geological Institute Special Papers, 14: 1-116.

Słodkowska, B., 2008. Palynostratigraphy of Paleogene deposits from the Yantarny P-1 profile (Sambian Peninsula, Russia). In: 12th International Palynological Congress and 8th International Organisation of Palaeobotany Conference, Abstract volume, Terra Nostra, 2: 250-260, Bonn.

Słodkowska, B., 2009. Palynology of the Palaeogene and Neogene from the Warmia and Mazury areas (NE Poland). Geologos, 15: 219-234

Słodkowska, B., Gałązka, D., 2015. Paleogene and Neogene sediments in mega-scale glaciotectonic structures oh the Dylewskie Hills (in Polish with English summary). Biuletyn Państwowego Instytutu Geologicznego, 461: 251-294.

Standke, G., 1998. Die Tertiärprofile der samländischen Bernsteinküste bei Rauschen. Schriftenreihe für Geowissenschaften, 7: 93-133.

Stuchlik, L., Ziembińska-Tworzydło, M., Kohlman-Adamska, A., Grabowska, I., Ważyńska, H., Słodkowska, B., Sadowska, A., 2001. Atlas of pollen and spores of the Polish Neogene, 1. Spores: 5-158. W. Szafer Institute of Botany, Polish Academy of Sciences, Kraków.

Stuchlik, L., Ziembińska-Tworzydło, M., Kohlman-Adamska, A., Grabowska, I., Ważyńska, H., Sadowska, A., 2002. Atlas of pollen and spores of the Polish Neogene, 2. Gymnosperms: 3-237. W. Szafer Institute of Botany, Polish Academy of Sciences, Kraków.

Stuchlik, L., Ziembińska-Tworzydło, M., Kohlman-Adamska, A., Grabowska, I., Słodkowska, B., Ważyńska, H., Sadowska, A., 2009. Atlas of pollen and spores of the Polish Neogene, 3 
Angiospemae (1): 3-233. W. Szafer Institute of Botany, Polish Academy of Sciences, Kraków.

Stuchlik, L., Ziembińska-Tworzydło, M., Kohlman-Adamska, A., Grabowska, I., Słodkowska, B., Worobiec, E., Durska, E., 2014. Atlas of pollen and spores of the Polish Neogene, 4. Angiosperms (2): 1-466. W. Szafer Institute of Botany, Polish Academy of Sciences, Kraków.

Wentworth, C.K., 1922. A scale of grade and class terms for clastic sediments. Journal of Geology, 30: 377-392.

Williams, G.L., Fensome, R.A., MacRae, R.A., 2017a. The Lentin and Williams Index of Fossil Dinoflagellates 2017 Edition. AASP-Contribution-Series-No.48.

Williams, G.L., Fensome, R.A., MacRae, R.A., 2017b. DINOFLAJ3. American Association of Stratigraphic Palynologists, Data Series, 2, http://dinoflaj.smu.ca/dinoflaj3
Zaddach, E.G., 1867. Das Tertiärgebirge Samlands. Schriften der Königlichen Physikalisch-Ökonomischen. Gesellschaft zu Königsberg, 8: 85-197.

Zagorodnykh, V.A., Kunayeva, T.A., 2005. Geologiya i poleznye iskopaemye Kaliningradskogo regiona (in Russian). Baltgeoresursy, Kaliningrad.

Zagorodnykh, V.A., Dovbnia, A.B., Zhamoida, V.A., 2001. Stratigrafiya Kaliningradskogo Regiona. Ministerstvo prirodnykh resursov Rossii, Departament prirodnykh resursov po Severo-Zapadnomu regionu, Kaliningrad.

Zatula, K.F., 1973. Kompleksy gistrigosfer iz yantaronosnykh otlozheniy Pribaltiki (in RUsian). Doklady AN SSSR, 212: 981-984. 